Int. J. Dev. Biol. 51: 609-631 (2007)

doi: $10.1387 /$ ijdb.072365lf

\title{
Mouse models to study inner ear development and hereditary hearing loss
}

\author{
LILACH M. FRIEDMAN, AMIEL A. DROR and KAREN B. AVRAHAM* \\ Department of Human Molecular Genetics and Biochemistry, Sackler School of Medicine, Tel Aviv University, Tel Aviv, Israel
}

\begin{abstract}
Hereditary sensorineural hearing loss, derived from inner ear defects, is the most common hereditary disability with a prevalence of 1 in 1000 children, although it can be present in up to $15 \%$ of births in isolated communities. The mouse serves as an ideal animal model to identify new deafness-related genes and to study their roles in vivo. This review describes mouse models for genes that have been linked with hearing impairment (HI) in humans. Mutations in several groups of genes have been linked with $\mathrm{HI}$ in both mice and humans. Mutant mice have been instrumental in elucidating the function and mechanisms of the inner ear. For example, the roles of collagens and tectorins in the tectorial membrane, as well as the necessity of intact links between the hair cell projections, stereocilia and kinocilia, have been discovered in mice. Accurate endolymph composition and the proteins which participate in its production were found to be crucial for inner ear function, as well as several motor proteins such as prestin and myosins. Two systematic projects, KOMP and EUCOMM, which are currently being carried out to create knockout and conditional mutants for every gene in the mouse genome, promise that many additional deafness-related genes will be identified in the next years, providing models for all forms of human deafness.
\end{abstract}

KEY WORDS: mouse, inner ear development, deafness gene, hearing

\section{Introduction}

\section{Hereditary hearing loss $(\mathrm{HHL})$ in humans}

Hearing impairment $(\mathrm{HI})$ is traditionally classified as conductive and sensorineural, based on the defective part of the hearing organ. While conductive $\mathrm{HI}$ results from defects in the external or middle ear, sensorineural $\mathrm{HI}$ results from a defect located along the auditory pathway, from the cochlea to the auditory cerebral cortex. A conductive defect yields a mild to moderate $\mathrm{HI}$ and in most cases may be medically solved. In contrast, a sensorineural defect yields a mild to profound $\mathrm{HI}$ and, thus far, sensorineurally hearing impaired persons may be aided with cochlear implants or hearing aids, but their problem cannot be completely solved [recently reviewed in (Petit, 2006)]. Therefore, further study is required to enable development of better therapies for sensorineural $\mathrm{HI}$.

At least $60 \%$ of persons with early-onset $\mathrm{HI}$ have hereditary hearing loss (HHL) due to genetic mutations. In most of these cases, a single mutation in a single gene is responsible for the hearing loss. About $70 \%$ of $\mathrm{HHL}$ cases in human are isolated or associated with a vestibular dysfunction only (non-syndromic hearing loss; NSHL), but HHL may be also accompanied with other abnormalities (syndromic hearing loss; $\mathrm{SHL}$ ). The onset of $\mathrm{HHL}$ may vary from birth to old age. Different mutations in the same gene may lead to both syndromic and non-syndromic HHL, as well as to different onset times (Van Camp and Smith, 2006). $\mathrm{NSHL}$ is inherited mainly (80\%) in an autosomal recessive manner. Sixty-three protein-coding chromosomal genes and seven tRNA or rRNA coding mitochondrial genes have been linked to $\mathrm{HHL}$ in humans [most of the genes are listed in the Hereditary Hearing Loss Homepage: http://webhost.ua.ac.be/hhh/ (Van Camp and Smith, 2006); additional genes are FGF3(Tekin et al., 2007) and SLC4A11 (Desir et al., 2007)]. The protein-coding genes

Abbreviations used in this paper: $\mathrm{ABR}$, auditory brainstem response; $\mathrm{BM}$, basilar membrane; ENU, N-ethyl-N-nitrosourea; EP, endocochlear potential; HHL, hereditary hearing loss; HI, hearing impairment; IHC, inner hair cells; NSHL, non-syndromic hearing loss; OHC, outer hair cells; PBM, PDZ binding motif; RP, retinitis pigmentosa; SHL, syndromic hearing loss; TM, tectorial membrane; WT, wild type.

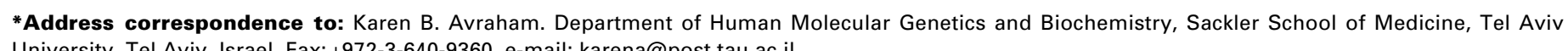
University, Tel Aviv, Israel. Fax:+972-3-640-9360. e-mail: karena@post.tau.ac.il

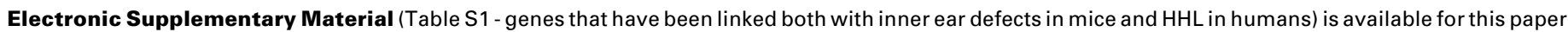
at: http://www.ijdb.ehu.es/web/paper.php?doi=072365lf 
include genes that encode for extracellular matrix components, gap junction and adhesion proteins, ion channels and transporters, other cell surface proteins and receptors, as well as myosins (molecular motors), cytoskeletal proteins, transcription factors and other proteins that interact with them to create hearingrelated networks.

If mutations in a given gene lead to defective development of the inner ear and to early-onset $\mathrm{HHL}$, the affected gene may be considered as having a role in inner ear development or function. A better understanding of inner ear development is required to understand the mechanisms by which specific mutations lead to HHL.

\section{Mouse models}

The study of sensorineural HHL in humans is limited by the inability to follow inner ear development. Genetic linkage analysis of $\mathrm{HHL}$ in humans is possible only in large families that contain several hearing impaired members. In addition, the search for the responsible gene in HHL patients may be more complicated than analysis of other inherited characters, since hearing-impaired persons from different families tend to marry each other and marriages between hearing children of hearing-impaired parents are also not rare. As a result, one family may carry two or more deafness-related mutations (Petit, 2006). Moreover, due to the absence of a satisfactory human cell line with similar characteristics to the developing inner ear, only primary cultures or model animals may be used to study the interactions between proteins expressed in the inner ear, their spatial and temporal expression patterns, their functions and for any other biological study.

Mutant mouse models that exhibit HHL due to inner ear defects may help to identify genes that have a role in the development or function of the inner ear. When a gene is suspected as responsible for $\mathrm{HHL}$ in humans, similar mutations may be engineered in mice to verify this hypothesis. Gene-targeted mutagenesis, or 'knockout' mice, may also be used to uncover the gene's role by comparison with wild type mice. Knockout mice have also been made for genes suspected as essential for hearing due to known interactions of their products with proteins encoded by other known deafness-related genes, or due to the expression of their products in the inner ear. In addition, mouse models are used to identify new genes that have a role in inner ear development and normal hearing. Many strains of hearing-impaired mice have

Fig. 1. Schematic illustration of the spatial expression of proteins which have been discovered to play a role in inner ear function both in mice and humans. (A) A schematic representation of a cross section through one turn of a wild type mammalian cochlea. Reissner's membrane (RM) separates the scala media from the scala vestibuli. In the organ of Corti, the tectorial membrane (green) covers the neuroepithelium, which contains sensory hair cells (three rows of outer hair cells and a single row of inner hair cells; shown in blue) and supporting cells (orange). The lateral stria vascularis (brown) has a crucial role in endolymph production. A grey arrow represents the main route of potassium cycling. (B) A schematic illustration of the tectorial membrane that is composed of two types of fibers: thin tectorin fibrils that compose the striated-sheet matrix (green) and heavy collagen bundles (black). (C) An illustration of the marginal cells of the stria vascularis. These cells laterally cover the lateral wall of the scala media (the endolymphatic space). Their apical plasma membranes contain kcnq1/kcne1 potassium channels (green) and pendrin (red). (D) An illustration of a single outer hair cell (OHC; blue), surrounded by two Deiters' supporting cells (yellow). A hair bundle lies on the apical surface of the OHC (box). Many prestin molecules (white rectangles) are expressed along the lateral walls of the $\mathrm{OHC}$, while kcnq4 potassium channels (green) are included in its basal membrane. Gap junctions, composed of connexins 26 and 30 (red), connect the two Deiters' cells. The OHC nucleus contains many transcription factors (TF) that were linked with HHL. (E) An enlargement of the hair cell hair bundle. The developing hair bundle contains a microtubules-containing kinocilium (blue projection) and actin-based stereocilia (black). The kinocilium is degenerated in the mature cochlear hair cells (Steyger et al., 1989), but persists in adult vestibular hair cells (Denman-Johnson and Forge, 1999). The stereocilia are connected by a dense network of links to the kinocilium and to adjacent stereocilia, while different links exist in mature and developing hair bundles [reviewed and photographed in (Frolenkov et al., 2004; Goodyear et al., 2005)]. Most of the intra-hair bundle links are illustrated, although not all links are present at the same time. The stereocilia in the mature hair bundle are interconnected by tip links (dark orange) and horizontal top connectors (brown). Tip links (dark orange) are oblique filamentous structures that connect the tops of two adjacent stereocilia with different heights and are thought to gate mechano-electrical transducer channels. Deflections of the stereocilia in the hair bundle toward the tallest row of stereocilia stretch the tip links and increase the open probability of these channels. Deflections of stereocilia in the opposite directions close these ion channels. Thus, tip links are an important component of the mechanotransduction apparatus. Horizontal top connectors (brown), also known as top links, couple adjacent stereocilia just below the tip links. While tip links also exist in the developing hair bundle, horizontal top connectors appear only at a relatively late stage of hair cell development. The developing hair cells also contain lateral (green) and ankle (light blue) links that are lost during development. The fine lateral links (green) are side links that connect adjacent stereocilia at their upper ends below the tip links. Ankle links (light blue) connect the stereocilia at their base and appear only for a short time during the postnatal period. During normal development, their loss is concomitant with the appearance of horizontal top connectors. The developing (and mature vestibular) hair bundles also contain kinocilial links (light orange) that connect the kinocilium to the tallest two or three stereocilia in the same hair bundle and are very similar to the tip links, as well as shaft links (red). Each link type is biochemically different from the others. Prestin molecules, which are expressed along the apical surface of supporting and hair cells (red), as well as cldn14 tight junctions (green) between supporting and hair cells are also shown. (F) An enlargement of a single stereocilium from the hair cell hair bundle. Protein complexes that are expressed at different developmental stages (in mature and developing stereocilia) are illustrated in the same figure, although in reality they are not expressed at the same time. The stereocilium cytoskeleton is based on F-actin filaments (brown). Integral proteins (cdh23, pcdh15, vlgr1, usherin) may dimerize with similar proteins of an adjacent stereocilium to compose lateral or tip links (dark blue rectangle), as well as ankle links (purple rectangle). Multi-protein complexes in the stereocilium, composed of proteins that have been linked with Usher syndrome, contain unconventional myosins (VIla or XVa; light blue) that can move along the F-actin filaments from the hair cell body to the stereocilium tip, harmonin-b (orange) and whirlin (green) that contain PDZ domains, and sans (fuchsia pink). The complexes contain several additional proteins that are not mentioned in this review, since they have not been linked yet with HI in mice [recently reviewed in (Kremer et al., 2006; Reiners et al., 2006)]. While tip links exist also in mature stereocilia, ankle links exist only in the developing stereocilia. The ankle link complex includes whirlin as well, but in the mature stereocilia whirlin expression is limited to the tip (Adato et al., 2005a; van Wijk et al., 2006). Myosin VI (red) is an additional unconventional myosin, but it moves along actin filaments in the opposite direction, from the plasma membrane into the cell, suggesting that it pulls down the hair cell apical plasma membrane between stereocilia (Cramer, 2000). 
arisen spontaneously during the last century. Moreover, coincidental mutagenesis of mouse chromosomes, by chemicals (mainly by ENU, N-ethyl-N-nitrosourea), by $\mathrm{X}$-ray radiation or by coincidental insertion of an extrinsic sequence («gene trap») has been used to create new hearing-impaired mouse strains. Identification of the responsible gene in such strains is much easier than genetic linkage analysis in humans. In fact, many deafnessrelated genes were identified in humans only after their identification in hearing-impaired mice (Supplementary Table S1).

Mutations in more than 172 different genes have been reported as responsible for inner ear malformations or dysfunction in mice (most of them are listed in the Jackson Laboratory's Hereditary Hearing Impairment in Mice database: http://www.jax.org/hmr/ master_table.html). Only 44 of them have already been linked to human $\mathrm{HHL}$ (these genes are listed in Supplementary Table S1). In addition, two genes that were linked with human $\mathrm{HHL}$ were found as not crucial for inner ear development and function in knockout mice (Table 1). Figure 1 illustrates the spatial expression of some of the proteins encoded by genes associated with $\mathrm{HHL}$.

Following the identification of the mutated gene, the mutant mice may be used to follow defective inner ear development and to identify specific roles of the gene products. Examples of assays that have been used to evaluate the outcome of deafness-related mutations are shown in Figures 2 and 3. Inner ear development and defects may be followed using bright field light microcopy (Figure 2, A-C), transmission (TEM; Figure 2, D-F) or scanning electron microscopy (SEM; Figure 2, G-J), as well as by paintfill analysis (Figure 2, K-L). Physiological assays may be used to measure ion currents and voltage potentials. The patch clamp assay may be used to measure currents or membrane potentials in a single cell. Length change in individual cells may be used to measure electromotility of outer hair cells (Figure 2, M-N). Temporal and spatial expression patterns of specific mRNAs or proteins in the cells may be observed by in situhybridization (ISH; Figure 2, O-P) and immunofluorescence (Figure 2, Q-V), respectively. Measurement of auditory brainstem response (ABR) to sound signals by scalp electrodes is the most widely used assay for evaluating hearing in mice (Figure 3, A-B). Vestibular defects may be assessed by swimming or other behavioral tests and may induce a characteristic circling behavior (Figure 3, C-E).

This review will describe mutant mouse models for some

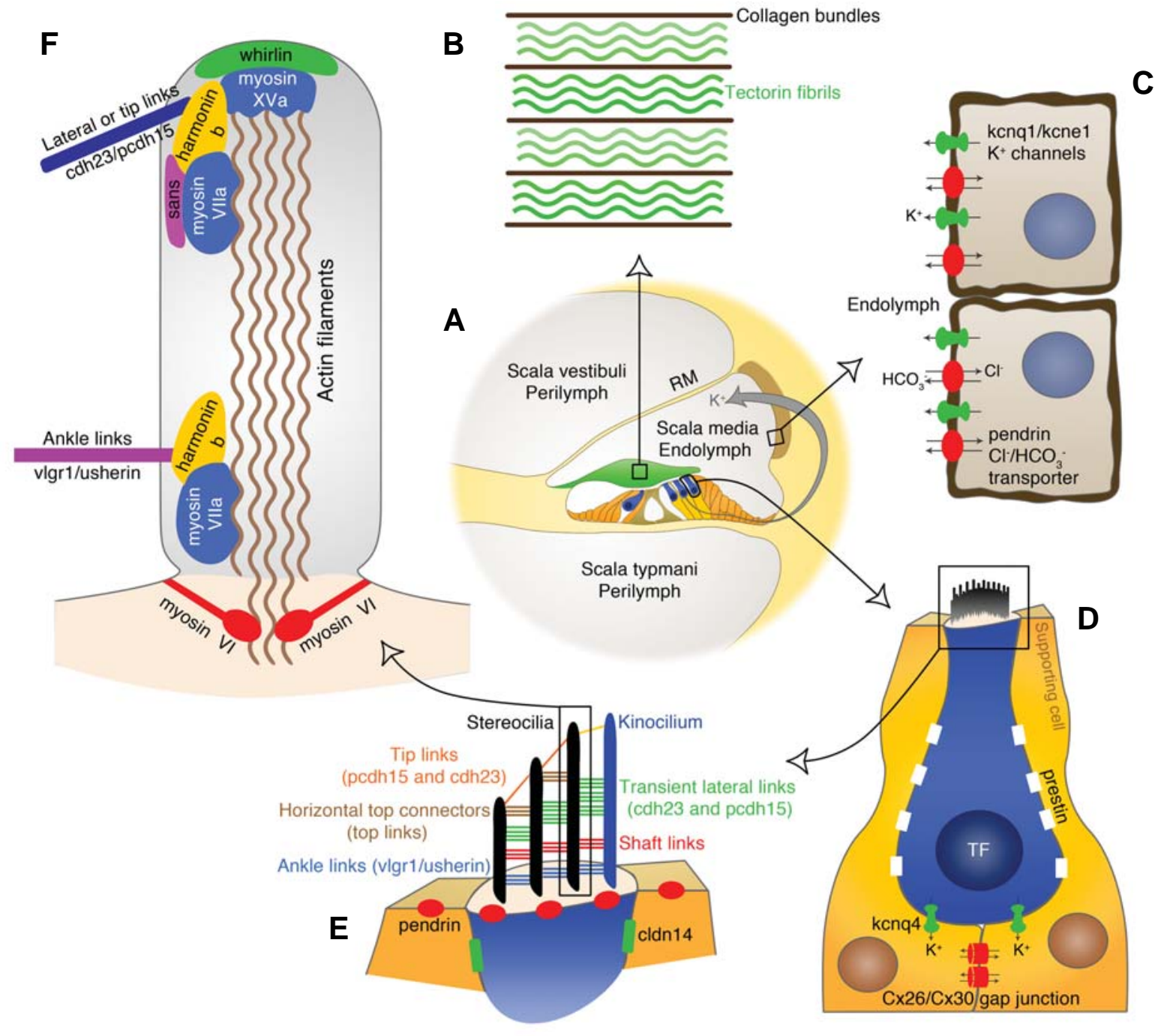




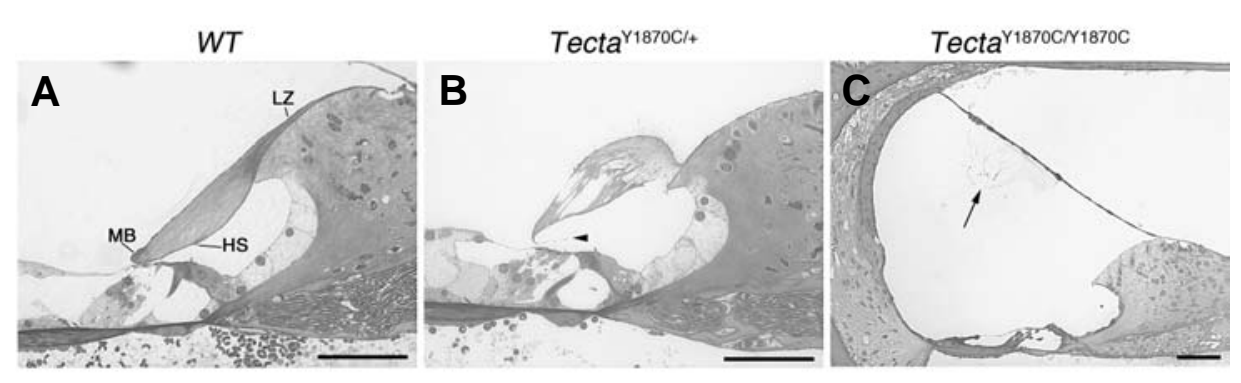

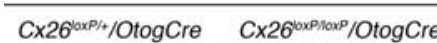
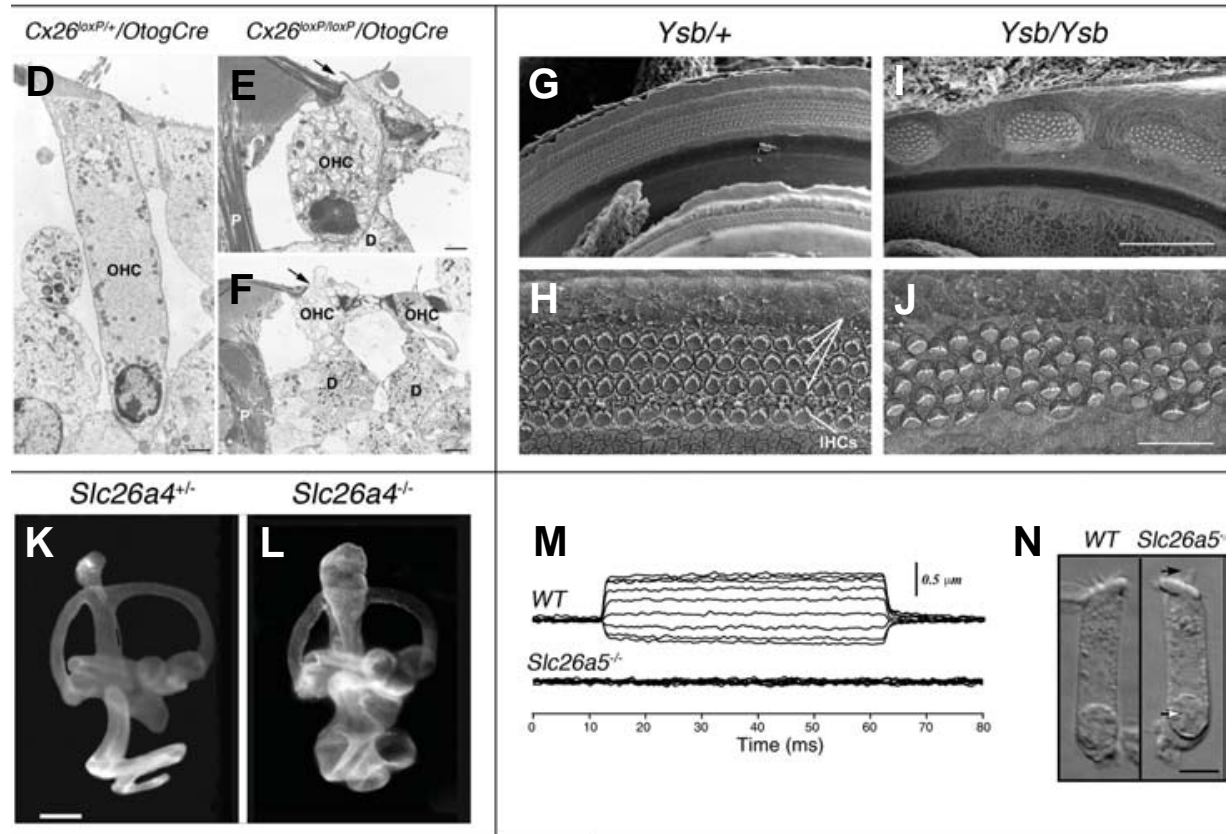

$$
\text { Slc26a4 }
$$

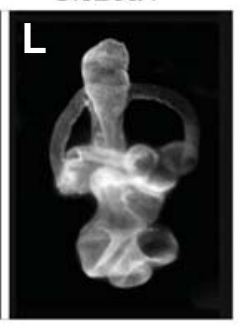

M

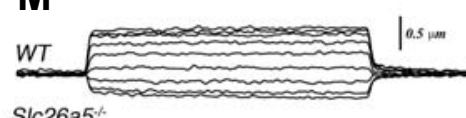

SIc26a5

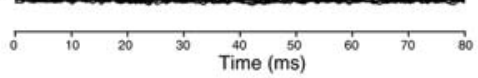

N
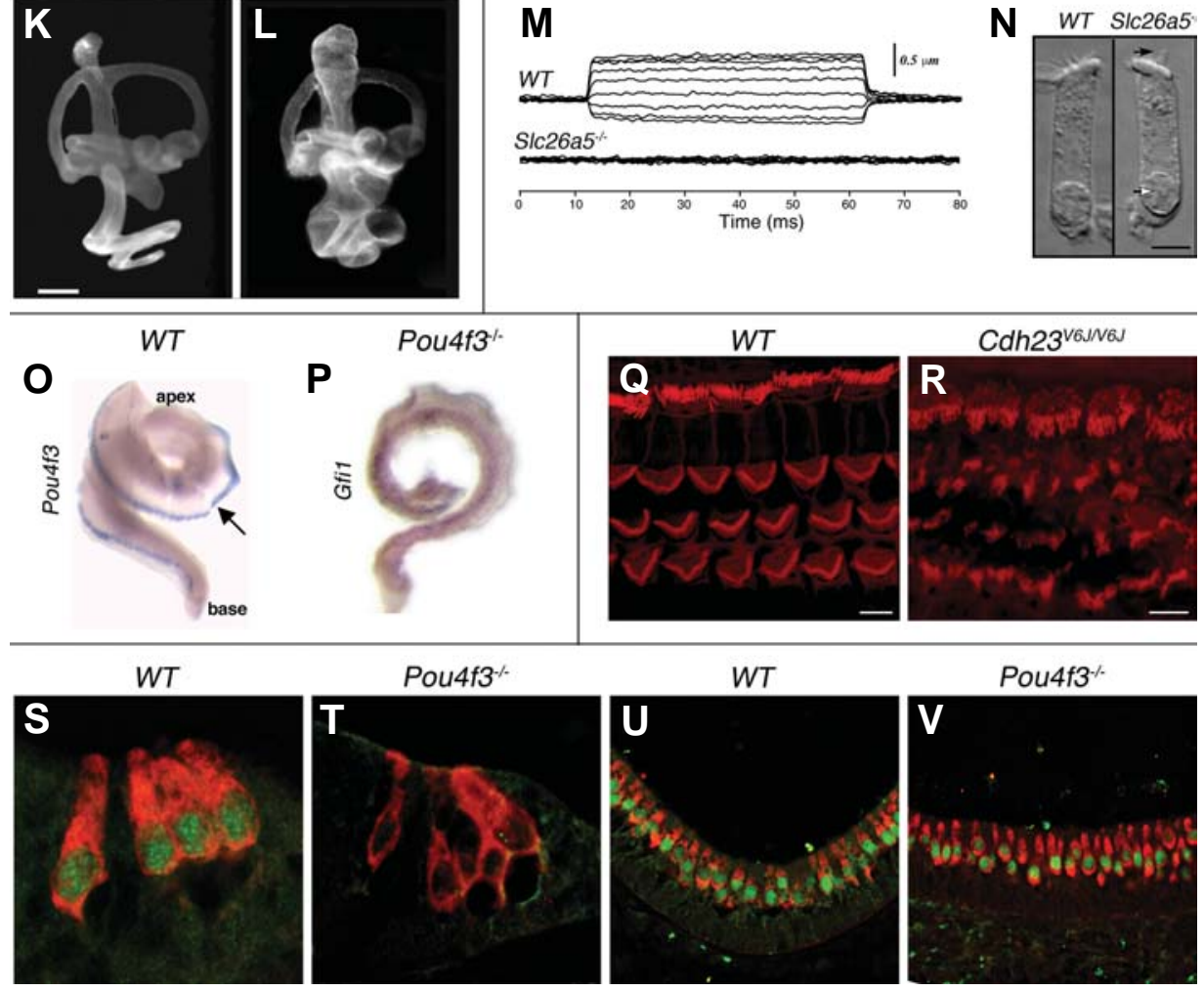

Fig. 2. Examples of assays which have been used to assess roles of specific genes in the mouse inner ear. (A-C) Light microscopic analysis (toluidine blue staining) of $1 \mathrm{~mm}$ thick sections of the cochlear duct from wild type (A), Tecta $11870 \mathrm{C} /+$ (B) and Tecta $\mathrm{Y} 1870 \mathrm{C} / \mathrm{Y} 1870 \mathrm{C}$ (C) mice. Abnormal and detached tectorial membranes are observed when Tecta is mutated. Abbreviations: $L Z$ - limbal zone, $M B$ - marginal band, HS - Hensen's stripe. Arrows: an arrowhead in (B) - Kimura's membrane, an arrow in (C) - tectorial membrane. Scale bars, $50 \mu \mathrm{m}$. Reprinted with permission from (Legan et al., 2005). (D-F) Transmission electron microscopy (TEM) of the organ of Corti at P30 from cochlea that expresses wild type connexin 26 (D), compared to cochlea in which the $\mathrm{C} \times 26$ gene was deleted (E-F). When CX26 is absent, damaged Deiters' cells do not stick to $\mathrm{OHC}$, leading to hair cell degeneration. Abbreviations: D-Deiters' cells, $P$-outer pillar cells. Arrows: disruption of the reticular lamina. Scale bars, $2.3 \mu \mathrm{m}$ in (D), $1.25 \mu \mathrm{m}$ in (E) and 0.8 $\mu \mathrm{m}$ in (F). Reprinted with permission from (Cohen-Salmon et al., 2002). (G-J) Scanning electron microscopy (SEM) of the organ of Corti basal portions at PO from yellow submarine (Ysb) heterozygous (G-H) and homozygous (I-J) mice. Ysb is a mutant allele of Sox2. Abnormal patches of hair cells are found in Ysb/Ysb mice. Three arrows in $(H)$ indicate the $\mathrm{OHC}$. Scale bars, $100 \mu \mathrm{m}$ in $(G, I), 20 \mu \mathrm{m}$ in (H, J). Reprinted with permission from (Kiernan et al., 2005). (KL) The paint-fill assay is used to present the endolymph labyrinth of the inner ear, in order to identify malformations within the inner ear cavities (Bissonnette and Fekete, 1996). These figures present lateral view of paint-filled $P 1$ inner ears from heterozygous (K) and homozygous (L) mice for the knocked-out allele of SIc26a4/ Pds (encoding pendrin). Slc26a $4^{-1-}$ mice exhibit dilated cochleae and endolymphatic ducts and sacs. Scale bar, $500 \mu \mathrm{m}$. Reprinted with permission from (Everett et al., 2001). (M-N) In vitro analysis of $\mathrm{OHC}$ electromotility in wild type and mutant (Slc26a5/Prestin knockout) mice. (M) Length changes of $\mathrm{OHC}$ in response to voltage steps (-120-60 mV in $20 \mathrm{mV}$ steps) in whole-cell, voltage-clamp recordings. (N) Micrographs of $\mathrm{OHC}$ isolated from apical turns of cochleae. $\mathrm{OHC}$ that do not express prestin are shorter than wild type OHC and do not exhibit electromotility. Arrows in (N): open arrow nucleus; filled arrow - stereocilia. Scale bar, 5 $\mu \mathrm{m}$ in (N). Reprinted with permission from (Liberman et al., 2002). (O-P) Whole mount in situ hybridizations (ISH) detect expression of Pou4f3 (O) and Gfi1 (P) mRNAs in E18.5 cochleae from wild type (O) and dreidel (P) littermate mice. Dreidel mice, which do not express functional Pou4f3 protein, do not express Gfi1 mRNA. Arrow-Pou4f3 mRNA expression is detected as a blue band along the lateral wall of the cochlea. Reprinted with permission from (Hertzano et al., 2004). (Q-R) Whole mount immunohistochemistry detects spatial expression pattern of F-actin (shown in red, stained with rhodamine phalloidin) in stereocilia in the middle turn of wild type $\mathbf{( Q )}$ and waltzer $\mathrm{V}^{6 J} \mathbf{( R )}$ organ of Corti at P7. The $\mathrm{V}^{6 \mathrm{~J}}$ allele was reported to be a functional null allele of Cdh23 (Di Palma et al., 2001 ; Di Palma et al., 2001b). Waltzer mice exhibit disorganized stereocilia (Lagziel et al., 2005). Scale bars, $5 \mu$ m. Figures from Ayala Lagziel and Thomas B. Friedman. (S-V) Immunohistochemistry of paraffin sections of E18.5 wild-type (S and U) and Pou4f3-1- (T and V) mouse inner ears. Expression of Lhx3 (green) and myosin VI (red) was detected in the cochlea (S-T) and the vestibular system utricle (U-V). Whereas Lhx3 is expressed in the nuclei of all hair cells in the wild-type inner ears, Lhx3 expression could be detected only in the vestibular system of the Pou4f3 ${ }^{-1}$ mice but not in any of the nuclei of the cochlear hair cells (Hertzano et al., 2007). Figures from Amiel Dror. 
representative genes that are crucial for normal development and function of the mammalian inner ear. We will focus mainly on genes for extracellular and integral inner ear proteins that were found to be involved both in human $\mathrm{HHL}$ and mouse inner ear development. Nonetheless, some examples for genes encoding for intracellular proteins will be also mentioned.

\section{Extracellular matrix components: cartilage and tecto- rial membrane defects (collagen genes and Tecta)}

The mammalian hearing organ, the organ of Corti, sits in the snail-shaped cochlea on a strand of connective tissue, the basilar membrane (BM). The collagen-based BM is graded in stiffness along the cochlea and vibrates in response to sound-induced movements of the cochlear fluids. These vibrations are detected by two types of hair cells, included in the sensory epithelium of the organ of Corti, the inner and outer hair cells (IHC and $\mathrm{OHC}$, respectively). The mechanosensory hair bundles of the $\mathrm{OHC}$ project up from the reticular lamina, the apical surface of the sensory epithelium and are embedded in the overlying tectorial membrane (TM) [reviewed in (Raphael and Altschuler, 2003)]. A cross section of the organ of Corti is illustrated in Figure 1A. The mammalian TM has a unique and highly organized ultrastructure. It contains two main groups of components: collagen fibrils that are organized in heavy bundles and run radially across the TM and glycoproteins that compose the unusual striated-sheet matrix surrounding the fibrils (schematically illustrated in Figure 1B) (Hasko and Richardson, 1988). Collagens types II, IX and XI compose the radial fibrils (Slepecky et al., 1992; Thalmann, 1993), while two glycoproteins, alpha and beta tectorins (encoded by Tecta and Tectb), are the major components of the TM matrix (Legan et al., 1997).

Seven collagen proteins were linked with human HHL: COL2A1, COL4A3, COL4A4, COL4A5, COL9A1, COL11A1 and COL11A2 (Van Camp and Smith, 2006). Only five of these have mouse models (Supplementary Table S1). A mutation in COL11A2was linked with autosomal dominant NSHL in humans (DFNA13 locus), but also with Stickler syndrome. The other collagen genes were only linked with SHL in humans, mainly Stickler (COL2A1, COL9A1 and COL11A1) and Alport (COL4A3-5) syndromes.

Alport syndrome-related collagens (chains alpha-3, 4 and 5 of collagen type IV) are included in basement membranes of the inner ear and the kidney's glomeruli. In the cochlea, they are expressed in the BM, parts of the spiral ligament and stria vascularis. As a result, Alport syndrome (Alport, 1927) combines sensorineural $\mathrm{HHL}$ and progressive nephritis, often progressing up to renal failure [reviewed in (Hudson et al., 2003)]. Following the identification of mutations in the human $C O L 4 A 3$ gene as responsible for Alport syndrome (Mochizuki et al., 1994), Col4a3 was knocked out in mice (Cosgrove et al., 1996). Homozygotes died at about 14 weeks of age due to renal failure. Defective basement membranes were found in the renal glomeruli and cochlear membranous labyrinth, similar to the human disease. The renal phenotype included progressive glomerulonephritis with proteinuria and microhematuria, focal multilaminated thickening and thinning of the glomerular basement membranes, as well as fibrotic glomeruli with collapsed capillaries. In the cochlear membranous labyrinth, both Col4a3 and Col4a4 chains were completely absent. Basement membranes of specific parts of the membranous labyrinth were significant thinner, thicker or undetectable compared to wild type cochleae and nearby capillaries were collapsed. Both renal and cochlear defects were progressive and $\mathrm{HI}$ was detected only after 6 weeks of age (Cosgrove et al., 1996; Cosgrove et al., 1998).

Stickler syndrome (Stickler et al., 1965) includes, in addition to a progressive sensorineural $\mathrm{HHL}$, premature degenerative changes in various joints with abnormal epiphyseal development, vertebral abnormalities, osteoarthritis and sometimes also unusual face and cleft palate. There are three types of Stickler syndrome: type 1 includes also progressive myopathy and blindness due to vitreoretinal degeneration and retinal detachment, while type 2 displays different vitreous defects with no retinal detachment [reviewed in (Snead and Yates, 1999)]. Type 3 is milder, with neither myopathy nor eye involvement (Vikkula et al., 1995). The Stickler syndrome-related collagens Col2a1, Col11a1 and Col11a2 are important components not only of the cochlear TM but also of the cartilage (Col2a1 is expressed also in the eye's vitreous). Since the inner ear has a cartilage cover, which has an important role in its embryogenesis, mutated collagens types II and $\mathrm{XI}$ affect the inner ear size, structure and development.

COL2A1 was found to be involved in sensorineural deafness that accompanies several similar hereditary syndromes in humans, such as Stickler syndrome, spondyloepiphyseal dysplasia congenita (SEDC) and chondrodysplasia. Dmm (autosomal semidominant disproportionate micromelia), a mouse with a mutated Col2a1 gene produced in 1966, is an offspring of a male whose spermatogonia had been irradiated. The $D \mathrm{~mm}$ mutation is a three-nucleotide deletion in the region encoding the $\mathrm{C}$-propeptide globular domain of Col2a1. The deletion leads to the replacement of two amino acids, Lys and Thr, by a single amino acid, Asn, in the mutated protein (Pace et al., 1997). Dmm mice expressed a reduced level of collagen II and suffered from cartilage defects

TABLE 1

\section{HEREDITARY HEARING LOSS (HHL)- LINKED GENES IN HUMANS, WHICH ARE NOT AS CRUCIAL FOR INNER EAR DEVELOPMENT AND FUNCTION IN MICE}

\begin{tabular}{|c|c|c|c|c|c|c|}
\hline Gene name & Full name & Main role of gene product & Human reference $^{\star}$ & Human syndrome & Mouse reference ${ }^{\&}$ & $\begin{array}{l}\text { Mouse strain } \\
\text { (mutagenesis method }^{\S} \text { ) }\end{array}$ \\
\hline$\overline{C o c h}$ & $\begin{array}{l}\text { Coagulation factor } \\
\text { C homolog, cochlin }\end{array}$ & $\begin{array}{l}\text { Unknown. Secreted protein, } \\
\text { most abundant protein in cochlea. }\end{array}$ & (Robertson et al., 1998) & NS & (Makishima et al., 2005) & $\operatorname{Coch}^{\sim}(\mathrm{KO})$ \\
\hline Myhg & $\begin{array}{l}\text { non-muscle myosin } \\
\text { heavy polypeptide } 9\end{array}$ & Actin-binding motor protein & (Lalwani et al., 2000) & NS (autosomal dominant) & (Parker et al., 2006) & $\begin{array}{l}\text { Myhgt/ (GT) Homozygotes } \\
\text { died during gestation }\end{array}$ \\
\hline
\end{tabular}

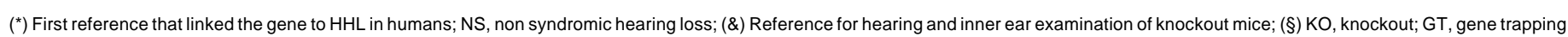


that affect inner ear development as well. The homozygotes were dwarf with disproportionate short limbs (micromelia), had a cleft palate (Brown et al., 1981; Seegmiller et al., 1988) and died at birth due to lung hypoplasia (Foster et al., 1994). Inner ears of homozygous Dmm embryos had less collagen fibrils and presented irregular cytodifferentiation of chondrocytes in the extracellular matrix, compared to wild type embryos (Berggren et al., 1997). As a result, dysmorphogenesis of the otic capsule and perilymphatic spaces during embryogenesis led to the development of malformed inner ears with a bulky cartilaginous capsule and a lack or reduction of defined perilymphatic spaces (Van de Water and Galinovic-Schwartz, 1987). More recently, a missense mutation in the mouse Col2a1gene was produced spontaneously (R1417C). These mice were named sedc, since their phenotype was similar to human spondyloepiphyseal dysplasia congenita. Homozygous sedc adult mice had shortened noses, dysplastic vertebrae, femora and tibias, retinoschisis and hearing loss (Donahue et al., 2003). Gene targeted mutagenesis was used to create Col2a1G574S mice, developed as a model for chondrodysplasia, following a parallel mutation that was found in humans. In addition to skeletal malformations, the mice were hearing impaired due to the development of a misshapen otic capsule. While the normal otic capsule is rounded, the transgenic otic capsule was flattened and elongated. The authors suggested that the weaker cartilage of the optic capsule could not resist the mechanical pressures from the developing brain and face and was squashed (Maddox et al., 1998). Heterozygote Col2a1 mutated mice displayed a milder but not normal phenotype.

Col9a 1 is an example to a gene that was linked to $\mathrm{HHL}$ in mice before its mapping to a deafness-related locus in humans. Col9a1knockout mice were raised as soon as 1994, but their inner ears were not studied and the observed phenotype was mainly noninflammatory joint disease resembling human osteoarthritis (Fassler et al., 1994). Only 11 years later, following the re-finding that Col9a 1 is highly expressed in the human inner ear (Abe et al., 2003) [collagens IX were found to be a major component of the TM also previously (Richardson et al., 1987)], the inner ears and hearing of Col9a1 knockout mice were studied (Asamura et al.,
2005). Indeed, these mice displayed a progressive hearing loss, most probably due to a disturbed organization of collagen fibrils in the TM, leading to an abnormal shape of this membrane. TM of Colga1 knockout mice contained neither collagens IX nor collagens II. Therefore, it was suggested that collagens IX and II may interact in the TM to determine its three-dimensional structure (Asamura etal., 2005; Suzuki etal., 2005). A year later, a mutation in COL9A1 was linked to an autosomal recessive Stickler syndrome in humans (Van Camp et al., 2006).

Cho mice arose spontaneously in 1971 (Seegmiller et al., 1971). Homozygotes had a cleft palate and died soon after birth due to lethal chondrodysplasia. The cho mutation is a 1-nt deletion in the Col11a1 gene that causes a frameshift and a premature termination codon, resulting in a truncated gene product that cannot assemble with other collagen molecules. Thus, chois actually a functional null allele of Col11a1 (Li et al., 1995). Homozygotes were severely hearing impaired at birth due to underdevelopment of the organ of Corti in the lower turn of the cochlea, with no hair cells, supporting cells, nerve endings and pillar cells (Cho et al., 1991). Since heterozygous chomice, which expressed both wild type and cho alleles of Col11a1, suffered from age-dependent osteoarthritis, it was suggested that the cho allele may have a destructive effect on connective tissues. However, heterozygous mice were well hearing during their first two months of life and developed a moderate and progressive hearing loss later (age-related) that was not significantly differ from wild type mice (Szymko-Bennett et al., 2003). In contrast to findings in mice, human $C O L 11 A 1$-linked $S H L$ is expressed also in heterozygotes: a point mutation in $C O L 11 A 1$ (G97V) was linked with an autosomal dominant Stickler syndrome (Richards et al., 1996) and a splice-donor-site mutation in this gene was linked with the similar autosomal dominant Marshall syndrome (Griffith et al., 1998).

Col11a2 was knocked out in mice by insertion of a neomycinresistance cassette in the reverse orientation in place of exons 27 and 28. The inserted sequence included a premature termination codon. Thus, the full length protein was not expressed. The phenotype was much milder compared to cho (functional null
Auditory Brainstem Response Test

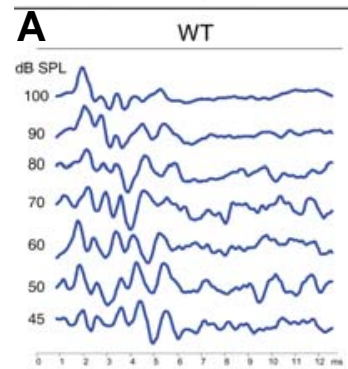

Reaching Response Test
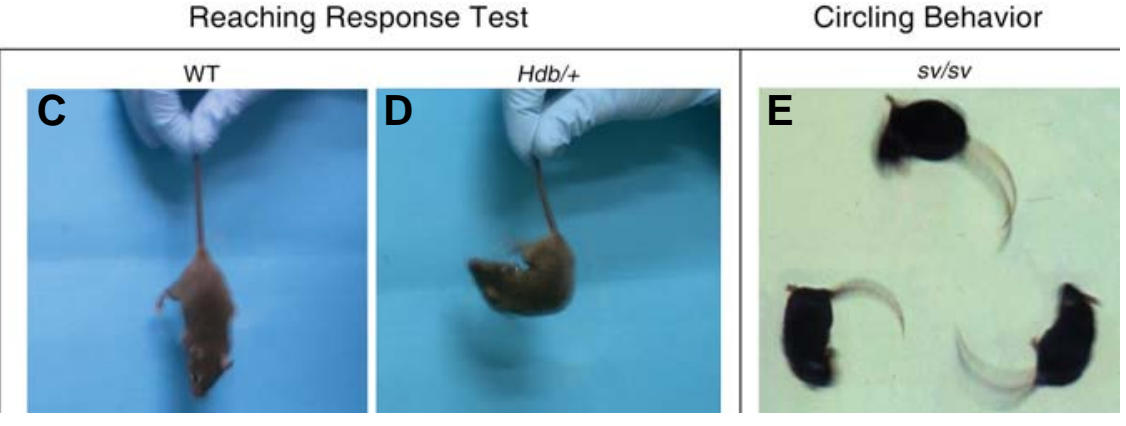

Fig. 3. Common behavioral tests for measuring and observing auditory and vestibular dysfunctions in mouse models. (A-B) Comparison between wild type and Pou4f3/- auditory brainstem response (ABR) tests. WT mice show typical graphs with peaks in response to various intensities (45-100 dB) of sound stimulations (A). Flattened graphs are observed in Pou4f3-- mice even at the highest sound level (100 dB), indicating the profound hearing loss of Pou4f3-- mice at the measured frequency of $16 \mathrm{KHz}$ (B). (C-D) Vestibular apparatus defects can be determined by reaching response. By holding their tails, normal mice will stretch out their legs to make contact with the underneath surface (C). Hdb (headbanger) is a dominant mutated allele of Myo7a, induced by ENU mutagenesis (Rhodes et al., 2004). Mice heterozygous for this mutation (Hdb/+) failed in recapitulate their three dimensional position, curling up towards their tails (D). Figures from Amiel Dror. (E) A Snell's waltzer mouse, which is homozygous for the sv allele of Myo6 (spontaneous mutation), exhibits circling behavior, which is another strong indicator for an abnormal balance system. 
Col11a1) mice. Homozygous mice had a smaller body size due to shorter long bones, receding snouts due to shorter nasal bones and hearing loss. The only morphologic abnormality observed in the inner ear was a larger and less compact TM with disorganized collagen fibrils (McGuirt et al., 1999; Li et al., 2001). The mild phenotype in homozygous mice correlates to the mild phenotype in humans (compared to mutations in other collagens): mutations in COL 11A2are responsible for a milder type of Stickler syndrome (type 3) with no eye abnormalities (Vikkula et al., 1995) and point missense mutations in this gene are responsible for NSHL (McGuirt et al., 1999).

Two mouse models with targeted mutations in Tecta (alpha tectorin) have been developed by the same group. Both mutations induced defective TM and HI. The first mutation was a targeted deletion in Tecta (named Tecta ${ }^{\triangle N N T}$ ). The only defect in the homozygous mice, which did not express alpha tectorin (null mutation), was observed in the TM, which lacked all noncollageneous matrix and was completely detached from the organ of Corti and spiral limbus. Their inner ears were less sensitive to sound stimulation, supporting the hypothesis that the TM amplifies the hair cell response to low level signals (Legan et al., 2000; Lukashkin et al., 2004). Examination of homozygous Tecta ${ }^{\triangle E N T /}$ $\triangle E N T$ mice, together with studying of the motion of the TM and BM of the organ of Corti [e.g. (Hemmert et al., 2000)], helped to uncover the roles of these membranes [For details, see (Legan et al., 2005)].

The second mouse model carried a missense mutation in Tecta (Legan et al., 2005), identical to the Y1870C mutation that had been found in hearing impaired humans (Verhoeven et al., 1998). Homozygous Tecta Y1870CYY1870C mice presented a detached TM with no tectorins, similar to the Tecta ${ }^{\triangle E N T A E N T}$ mice. Heterozygous Tecta ${ }^{Y 1870 C+}$ mice displayed a disrupted and partially thinner TM that expressed tectorins and was still partially attached to the organ of Corti (Figure 2, A-C). Although the interactions between the heterozygote $\mathrm{TM}$ and $\mathrm{OHC}$ seemed normal, with an almost normal transport of feedback from $\mathrm{OHC}$ to $\mathrm{BM}$, the sensitivity for sound signals was reduced due to an elevation in the neural activation thresholds. The space between the $\mathrm{TM}$ and the $\mathrm{IHC}$ was enlarged in heterozygotes and $\mathrm{IHC}$ and reticular lamina movements were specifically reduced at the characteristic frequency. Thus, the heterozygous Tecta ${ }^{\text {Y1870Cl+ }}$ mice helped to suggest a second role for the TM: although IHC hair bundles are not imbedded directly in the TM, the TM has still a role in transmitting the $\mathrm{BM}$ vibrations to the $\mathrm{IHC}$ in the characteristic frequencies. In other words, the TM adjusts the BM vibrations to optimally stimulate $\mathrm{IHC}$ at their best frequencies (Legan et al., 2005). This hypothesis was supported recently by a physiological study, suggesting that the hair bundles of the IHC are moved in response to fluid movements in the narrow space between the IHC and the TM. These fluid movements result from the TM vibration and movements of the $\mathrm{OHC}$ hair bundles (Nowotny and Gummer, 2006).

While mutations in TECTA have already been linked to NSHL in humans (Hughes etal., 1998; Verhoeven etal., 1998; Mustapha etal., 1999), TECTBmutations have not been found yet in hearing impaired persons. However, knockout mice for beta-tectorin were recently reported. Although the TM matrix in homozygous mice was disrupted, their inner ears were less sensitive only for low frequency tones, while in high frequencies the frequency resolu- tion was sharpened with little or no loss of sensitivity (sharpness cochlear tuning). These results suggest a third role for the TM: to affect cochlear frequency resolution (Russell et al., 2007).

\section{Intra-hair bundle link proteins: Cdh23, Pcdh15, VIgr1 and Ush2a}

Usher syndrome is the most common etiology for a combination of hereditary deafness and blindness. This disease combines congenital sensorineural hearing loss and a progressive loss of the visual field due to retinitis pigmentosa (RP) that leads to a progressive retinal degeneration. Three clinical subtypes of Usher syndrome have been described. These types differ by the onset time and character of the hearing loss, onset time of the RP and involvement of vestibular dysfunction [recently reviewed in (Nikolopoulos et al., 2006)]. Thus far, mutations in nine genes have been linked to Usher syndrome in humans. Five of these genes have been also linked to NSHL in humans: MYOVIIA, USH1C/Harmonin, CDH23, PCDH15 and VLGR1/MASS1 (Van Camp and Smith, 2006). Mouse mutants are currently available for eight of the Usher-linked genes. The proteins encoded by Usher genes belong to different classes and have different functions. However, all these proteins have a role in the molecular function, development and/or maintenance of the hair cell hair bundle. Recently it was established that all the Usher-related proteins are bound (directly or indirectly) to each other through the harmonin's PDZ sites and form a multi-protein unit that may be shuttled (via the motor myosins myosin VIla and/or myosin XVa) along the hair cell's actin filaments to their site of action within the stereocilia (Figure 1F) [recently reviewed in (Kremer et al., 2006; Reiners et al., 2006)]. Four Usher-related genes encode for adhesion proteins (cadherin 23, CDH23; protocadherin 15, PCDH15; Very Large G-protein coupled Receptor-1, VLGR1/ MASS1; and usherin, USH2A). The other Usher-related genes encode for intracellular hair cell proteins (Supplementary Table S1). The roles of Usher-related proteins in the eye have recently been reviewed (Reiners et al., 2006).

Stereocilia are highly specialized microvilli with an actin core that project from hair cells to the endolympahtic space. In the hair bundle, the stereocilia are arranged in rows with a special staircase pattern (illustrated in Figure 1, D-F). In mice, hair bundle development extends from embryogenesis into the first two weeks after birth. The Usher-related adhesion proteins participate in inter-stereociliar links essential for mechanotransduction, a process where the cochlear and vestibular hair cells translate mechanic movements of their hair bundles to electrochemical signals. In the mammalian inner ear, developing and mature hair bundles are considerably different (for details, Figure 1E legend).

Cadherin 23 (also known as otocadherin, Cdh23) and protocadherin 15 (Pcdh15) are transmembrane proteins with a short intracellular and a long extracellular domain, which are atypical members of the cadherin superfamily. All cadherin molecules contain cadherin domains ('EC' domains) along their extracellular portion, which mediate $\mathrm{Ca}^{2+}$-dependent dimerization of cadherin molecules. Dimerization of cadherin proteins from two neighboring cells links the cells [reviewed in (Reiners et al., 2006)]. In their cytoplasmic tail, cadherin 23 and protocadherin 15 contain class I-PDZ binding (PBM) motifs that can bind PDZcontaining proteins. Therefore, they can bind harmonin. Through 
harmonin, the Usher-related cadherins are linked to cytoskeletal actin filaments and are part of the Usher-related multi-protein unit (Siemens et al., 2002; Adato et al., 2005b)].

In wild type mouse inner ears, cadherin 23 was localized to the hair cell stereocilia and Reissner's membrane (Wilson et al., 2001; Boeda et al., 2002; Lagziel et al., 2005). In the mouse hair bundle, cadherin 23 was localized along the length of growing stereocilia and to the tips of mature stereocilia. More precisely, cadherin 23 was localized to links between stereocilia in the hair bundle (Boeda et al., 2002; Siemens et al., 2002; Siemens et al., 2004; Lagziel et al., 2005; Michel et al., 2005; Rzadzinska et al., 2005). Two splice variants of Cdh23 were found in the mouse inner ear. Both have PDZ-binding motifs that can bind harmonin. A truncated cadherin 23 that lacks the extracellular domain was also reported [reviewed in (Reiners et al., 2006)]. Protocadherin 15 is widely expressed in many tissues in mice (Alagramam et al., 2001a; Murcia and Woychik, 2001) and humans (Alagramam et al., 2001b), including the brain, cochlea and vestibule, from early development through adulthood. In the developing cochlea, protocadherin 15 was localized to the apical surface of hair cells, supporting cells, outer sulcus cells and spiral ganglion cells, while mature cochleae express protocadherin 15 only in hair cell stereocilia (Alagramam et al., 2001b).

Many mutant mice for Cdh23 are available. Four different mutations in Cdh23arose spontaneously in mice: waltzer(Deol, 1956; Di Palma et al., 2001a; Wilson et al., 2001; Lagziel et al., 2005), waltzerniigata (Wada etal., 2001), modifier of deafwaddler - mdfw (Bryda et al., 2001) and age-related hearing loss - Ahl (Noben-Trauth et al., 2003). Injections of chemicals to male mice were also used to generate Cdh23 mutated offspring. Both chlorambucil, that induces deletion mutations [Albany-waltzer (Bryda et al., 1997)] and ENU, that induces point mutations (three types of waltzer-Jackson alleles; reported only in the Mouse Genome Database: http://www.informatics.jax.org) gave rise to Cdh23 mutated mice. Seven of these Cdh23-mutated mouse strains (except $A h$ ) displayed a similar phenotype: NSHL with circling behavior, head tossing and erratic movements that appear in homozygotes from birth. Heterozygotes appeared normal at birth, but had a tendency to develop a progressive hearing loss at older ages and had a higher sensitivity for noise-induced hearing loss (Holme and Steel, 2004). The Ah/allele is a naturallyoccurred $C d h 23^{G 753 A}$ dimorphism that appears in many common laboratory inbred mouse strains. The replacement of guanosine 753 by adenosine causes in-frame skipping of exon 7, resulting in the tendency to develop a progressive hearing loss during aging and a higher sensitivity for noise-induced hearing loss (Davis et al., 2001; Noben-Trauth et al., 2003).

Waltzer mouse mutants exhibit a progressive disorganization of the hair bundle, which is first observed at the beginning of the bundle formation at embryonic day 18.5 (E18.5) and becomes more pronounced as the hair cells mature (Figure 2, Q-R). In addition, the kinocilium is misplaced. At older age, stereocilia seem thicker and fused, leading to hair cell degeneration (Di Palma et al., 2001a; Wada et al., 2001; Holme and Steel, 2002). C57BL/6J mice, which are homozygous for the Ah/allele, display hair cell degeneration in old age, more pronounced in the apical part of the cochlea. OHC are affected more than the IHC. Degeneration of the efferent nerve fibers was also observed (Mizuta et al., 1993). In the developing mouse inner ear hair cell, cadherin 23 was located both in kinocilial and transient lateral links (Boeda et al., 2002; Lagziel et al., 2005; Michel et al., 2005), but waltzer mutated cadherin 23 was absent only from lateral links. Cadherin 23 was observed along kinocilia of mature vestibular hair cells as well (Lagziel et al., 2005). Hair cells of Cdh23deficient zebrafish mutants lacked tip links and these fish had balance and hearing defects (Sollner et al., 2004). Two groups reported that cadherin 23 in mice is also a component of the tip links between stereocilia of the cochlear and vestibule hair bundles. Moreover, cadherin 23 has biochemical properties similar to those of the tip link. Therefore, it was suggested that cadherin 23 composes the tip link that regulates the mechanically gated ion channels in hair cells stereocilia (Goodyear and Richardson, 2003; Siemens et al., 2004).

The first mouse model for a mutated Pcdh15 was Ameswaltzer (av). Originally, Ames-waltzer mice were reported in 1956 as carrying a recessive spontaneous mutation causing deafness, circling behavior, head-tossing and hyperactivity, similar to the waltzer ( $v$ phenotype (Schaible, 1956). In the following years, several mutations in the same locus arose independently, resulting in similar phenotypes. The mutated gene was found to be $P c d h 15$ in an Ames-waltzer allele that was raised in transgenic mice following insertional mutagenesis (Alagramam et al., 1999). Circling behavior and a reduced AM1-43 dye uptake, that had been shown to correlate with normal transduction function in hair cells, preceded structural defects in the vestibule that could be observed by light or scanning electron microscopy. The functional defect led to disorganization of stereocilia in the cochlea and saccule, which resulted in hair cell dysfunction and progressive degeneration. While inner ears of P10 homozygotes displayed only abnormal stereocilia in the cochlea, saccular stereocilia began to be disorganized only at P30 and inner ears of adult homozygous mice (P50 or older) presented an almost complete degeneration of the cochlea's organ of Corti and vestibular saccular macula (both supporting and hair cells were absent). In the cochlea, a secondary degeneration of the spiral ganglion neurons was also observed. The neuroepithelia of the utricle and the semicircular canals cristae appeared normal, but the utricular otoconia were large and malformed (Alagramam et al., 1999; Alagramam et al., 2001a; Alagramam et al., 2005). In another spontaneous Pcdh15 mutant, resulting from an insertion of a cytosine residue which led to a frame-shift and premature stop codon, the phenotype was very similar, although the mice were not completely deaf but only hearing impaired. Disorganization of cochlear stereocilia was observed in newborns (P0) (Hampton et al., 2003). An ENU-induced Pcdh 15 mutated mouse presented a similar phenotype as well, with cochlear stereocilia disorganization not before the age of P2. In the cochlea, IHC were less affected compared to OHC (Washington et al., 2005). The three models described above are homozygous for functional null alleles. Milder phenotypes were reported in mice homozygous to less severe mutations in Pcdh15 (Pawlowski et al., 2006).

In mouse inner ear hair cells, several isoforms of protocadherin 15 are expressed and two of them were suggested to be part of the tip and kinocilial link complexes in the hair bundles. Another isoform may be associated with transient lateral links between developing stereocilia and to kinocilial links, since the expression pattern of this isoform was similar to that of cadherin 23 (Ahmed et al., 2006). 
The VIgr1/Mass /gene in mice is transcribed to several splicing variants that encode integral and secreted proteins. The longest isoform, VIgr 1b, which is approximately $19 \mathrm{~kb}$ is size, is translated to the largest known cell surface protein (approximately 6300 amino acids), containing a large extracellular domain. Its intracellular domain contains a PBM motif that may interact with harmonin's PDZ domain. Although the VIgr1b protein has a typical structure of a G-protein coupled receptor with seven transmembrane domains, its function is unknown (McMillan et al., 2002; Yagi et al., 2005). Mass 1 is a smaller (approximately 9400 bases) splice variant of VIgr1. VIgr1 receptors are expressed predominantly in the neuroepithelium of the mouse developing brain (Yagi etal., 2005) and VIgr1mutations, in particular mutated VIgr1band Mass 1 transcripts, have been associated with audiogenic seizures in mice (Skradski et al., 2001; McMillan and White, 2004; Yagi et al., 2005) and seizures in humans (Nakayama et al., 2002). The extracellular domains of Vlgr1 receptors contain multiple repeated units of $\mathrm{CalX}-\beta$ modules that bind $\mathrm{Ca}^{2+}$ cations and may have a role in $\mathrm{Ca}^{2+}$-dependent intercellular adhesion. It was also proposed that these modules may monitor the extracellular $\mathrm{Ca}^{2+}$ level and participate in intra- and extra-cellular $\mathrm{Ca}^{2+}$ trafficking (Nikkila et al., 2000; Weston et al., 2004). Additional motifs in the extracellular domains of Vlgr1 proteins were suggested to interact with other Usher-related proteins [reviewed in (Reiners et al., 2006)].

The first mouse model for mutant VIgr1 was Mass ${ }^{\text {Frings }}$, which arose spontaneously in 1951 (Frings et al., 1951), serves as a mouse model for epilepsy due to its susceptibility to loud noiseinduced seizures. The BUB/BnJ inbred mouse strain is homozygous for the Mass $1^{\text {Frings }}$ mutation and displays both audiogenic seizures and progressive hearing loss that begins postnatally and progresses to complete deafness (Zheng et al., 1999; Skradski et al., 2001). BUB/BnJ mice are also homozygous for the $A$ h/allele of $C d h 23$, but this fact does not explain the deafness of all these mice, since in other strains homozygous to $A$ h/the probability and severity of hearing loss are much lower. The association of VLGR1mutations with $\mathrm{HHL}$ included in Usher type II syndrome in humans (Weston et al., 2004) raised the possibility that the Mass $1^{\text {Frings }}$ mutation underlies hearing loss in BUB/BnJ mice. Indeed, it was shown that the co-mutation of Cdh23and VIgr1 is responsible for most of the severe hearing loss in BUB/BnJ mice. In young BUB/BnJ mice, the cochlear stereocilia developed abnormally and remained immature. Stereocilia were disconnected and detached, sometimes found outside their unit and the most severely affected bundles lost their polarity and graded height. At older ages, hair cells and spiral ganglion cells were degenerated (Johnson et al., 2005).

Wild type VIgr1 receptors expression in the inner ear was found to be limited to the synapse region and the hair cell stereocilia, both in the vestibule and cochlea. In hair cells, VIgr1 receptors were expressed only at the base of developing stereocilia in the same location and timing as ankle links: their expression is maximal at the perinatal period and diminished during hair cell development. A monoclonal antibody that is used to identify ankle links in chickens was found to bind the avian ortholog of Vlgr1b. Two mouse models with mutant VIgr/ were developed: (a) knockout mice that express no VIgr1 proteins (Yagi et al., 2005) and (b) Vlgr1/del7TM mice, in which a targeted deletion was used to delete the transmembrane domain of Vlgr1 (McGee et al., 2006).
In both models, VIgr1 receptors deficiency resulted in similar cochlear abnormalities. Homozygous mice did not display ankle links between the hair cell stereocilia. Although the hair bundles seemed normal at birth, they became disorganized thereafter. Mice homozygous for mutant VIgr1developed profound deafness by the third week of life and from this age displayed disorganized hair bundles, including displaced kinocilia, resulting in distorted stereocilia development. Thus, the VIgr1 receptor is proposed to be a crucial member in the ankle link complex. Surprisingly, although developing vestibular hair bundles have ankle links and express Vlgr1 as well, only cochlear hair cells were damaged in homozygous mice. Vestibular cells were not degenerated and a vestibular phenotype was not observed, corresponding with a lack of vestibular symptoms in Usher II patients (McGee et al., 2006; Yagi et al., 2007).

Another integral Usher-related protein, usherin (encoded by the long transcript of Ush2a), was also suggested to be a component of the ankle links in developing stereocilia (Adato et al., 2005a). In humans, USH2A mutations are responsible for the most common genetic form of Usher syndrome (Eudy et al., 1998). Similarly, while knockout Ush2a-- mice exhibited a progressive degeneration of photoreceptor cells, their hearing was only moderately affected, presenting moderate and non-progressive $\mathrm{HI}$ at higher frequencies. Although usherin was predicted as part of the ankle protein and was detected mainly in the base of developing stereocilia in both inner and outer hair cells (from E20) along the entire cochlea, Ush2a- mice presented normal hair bundles and lost only $\mathrm{OHC}$ in the basal turn of the cochlea (Adato et al., 2005a; Liu et al., 2007).

The studies reviewed above suggest that the expression of link molecules early in the development of the hair bundle is essential for its correct formation and maturation. Correct maturation of the hair bundle is crucial for hair cell survival.

\section{Genes responsible for endolymph production}

The cochlea contains two segregated fluid-filled compartments with different ion concentrations (Figure 1A). The perilymphatic space contains the perilymph, a high $\mathrm{Na}^{+}$and low $\mathrm{K}^{+}$ solution, similar to other body extracellular fluids. The apices of the hair cells face the endolymph, which has an opposite cationic composition of high $\mathrm{K}^{+}$and low $\mathrm{Na}^{+}$, while their basolateral surface is bathed in perilymph. Circulation of potassium cations in the cochlea from perilymph to endolymph through the cochlear lateral wall and maintenance of the unique ion composition of the endolymph, are essential for auditory function. Studies in mouse models for mutated proteins that are involved in $\mathrm{K}^{+}$recycling in the cochlea helped to establish the recycling mechanism. Acoustically evoked receptor potentials are generated by the influx of $\mathrm{K}^{+}$ ions from the endolymph into hair cells. These $\mathrm{K}^{+}$ions are then secreted basolaterally to the extracellular space of the organ of Corti and picked up by supporting cells. Thereafter, $\mathrm{K}^{+}$ions are transported laterally toward the spiral ligament through gap junctions between supporting cells and from supporting cells to root cells, released to the extracellular space of the spiral ligament and then, by a second network of gap junctions between connective tissue fibrocytes, the cations are transferred toward the stria vascularis. $\mathrm{K}^{+}$ions pass the basement membrane between the connective tissue and stria vascularis epithelial cells through tight 
junctions and are released from the epithelial basal cells to the extracellular space of the stria vascularis. Then, stria vascularis marginal cells take up the $\mathrm{K}^{+}$ions and release them back into the endolymph. Stria vascularis marginal cells and Deiters' cells, as an example for supporting cells, are illustrated in Figures $1 \mathrm{C}$ and $1 \mathrm{D}$, respectively. A similar recycling pathway exists in the vestibule. This description is somewhat simplistic, since some of the $\mathrm{K}^{+}$leakage from the endolymph is through outer sulcus cells and Reissner's membrane [reviewed and illustrated in (Kikuchi et al., 2000; Wangemann, 2002)].

Several genes that account for $\mathrm{HHL}$ in humans encode proteins that participate in $\mathrm{K}^{+}$circulation in the cochlea. Mutated mouse models were developed for the following genes: (a) Gjb2/ $C \times 26, G j b 6 / C \times 30$ and $C / d n 14$ that encode intercellular adhesion proteins: Gjb2and Gjb6 genes encode the gap junction proteins connexin 26 (Cx26) and connexin 30 (Cx30), while Cldn14 encodes a tight junction protein; (b) Kcne1, Kcnq1and Kcnq4that encode potassium ion channels; and (c) S/c26a4that encodes an anion transporter.

Gap junctions are channels interconnecting two cells and allow a rapid transport of wide variety of ions and small molecules (including nucleotides, siRNAs and inositol phosphates) between the connected cells. Gap junctions are composed of closely aggregated intramembranous channel particles (connexons), which in turn are hexameric assemblies of connexin proteins. The inner ear hair cells do not contain gap junctions. Two distinct networks of gap junctions exist in the cochlea: between connective tissue cells and between non-sensory epithelial cells. Cx26 and $\mathrm{C} \times 30$ are part of both cochlear gap junction systems and can co-assemble to form hybrid (heteromeric) gap junctions. However, the predominant connexin isoform expressed in cochlear supporting cells is Cx26 (Ahmad et al., 2003; Forge et al., 2003; Buniello et al., 2004).

In the human genome, $G J B 2$ and $G J B 6$ genes are located in the same chromosomal locus (DFNB1, 13q11-12). Mutations in this locus account for a high proportion of congenital hereditary NSHL with variability depending on the population [approximately 30-60\%; e.g. (Zelante et al., 1997)]. GJB2mutations are the most prevalent inherited source of deafness in humans $(30-50 \%$ of prelingual hereditary NSHL cases). In most of these cases, the responsible mutations are small deletions in the GJB2 gene and the inheritance type is autosomal recessive. However, few cases of dominant inherited SHL due to GJB2 mutations were also reported. Thus far, more than a hundred deafness-related different mutations in $G J B 2$ have been identified in humans. Large deletions in the $G J B 6$ gene can also cause deafness in homozygotes. In addition, a combination of a large deletion in $G J B 6$ and a point mutation in GJB2 can induce NSHL in heterozygotes [Connexins and Deafness Homepage; http://davinci.crg.es/deafness/ (Ballana et al., 2007)].

Two different approaches, targeted mutagenesis (Gabriel et al., 1998) and ENU-induced mutagenesis (Coghill et al., 2002), were used to knock out the Gjb2/Cx26 gene in mice. Both approaches led to birth of well hearing heterozygous offspring only, while homozygous embryos died in utero due to placental defects. Two additional strategies were taken to generate mutant Gjb2mouse models that will be both hearing impaired and viable. Gjb2 was specifically knocked out in the cochlear epithelial network (supporting and flanking epithelial cells), using the con- ditional cre-loxP system to generate mice that are homozygous for Gjb2-loxP and carry Cre after an Otog promoter, which is expressed only in cochlear epithelial cells (Figure 2, D-F) (CohenSalmon et al., 2002). In a second approach, targeted point mutagenesis was used to replicate the Cx26 R75W mutation (Kudo et al., 2003) that is responsible for autosomal dominant SHL (HHL and skin disease) in human heterozygotes (Richard et al., 1998). The dominant inheritance was explained by the ability of the mutant Cx26 to inhibit the function of gap junctions that coassemble wild type and mutant Cx26 molecules (Richard et al., 1998).

Both Gjb2 knockout homozygotes and $C \times 26^{R 75 W}$ heterozygotes exhibited similar $\mathrm{HI}$ in adults and histological phenotypes, although the second model displayed a more severe phenotype. In both models, the inner ear development was normal until postnatal day 14 (P14). Only after onset of hearing, at P15-P16, epithelial cells began to die due to apoptosis. The IHC-neighboring supporting cells were first damaged. Thereafter, $\mathrm{OHC}$ and their supporting cells began to die. The tunnel of Corti was collapsed. $C \times 26^{R 75 W}$ heterozygotes displayed degeneration of all organ of Corti that began at P14 and led to a complete degeneration of both hair cells and supporting cells by seven weeks of age. In Gjb2 knockout mice, IHC died only in the more profoundly hearing impaired mice (but displayed immature synapses even when they survived) and some of the intradental cells of the spiral limbus were degenerated at older age (P60). The reticular lamina at the apical surface of the sensory epithelium, which is composed of tight junctions between hair cells and their supporting cells, was disrupted from an early stage in Gjb2knockout mice (Figure 2, EF). Therefore, Cx26 seems to be essential for survival and function of the organ of Corti, but is not required for its normal development. Differences between the models were observed in the maintenance of electric potential difference between the endolymphatic and perilymphatic compartments of the cochlea, represented by the endocochlear potential (EP). In Gjb2knockout mice, endolymphatic $\mathrm{K}^{+}$concentration and EP were much lower in homozygous mice, as expected, supporting the hypothesis that Cx26-based gap junctions are required for $\mathrm{K}^{+}$recycling in the cochlea. Surprisingly, EPs of $C \times 26^{R 75 W}$ heterozygotes were normal, suggesting that the reason for apoptosis of organ of Corti cells in the presence of a mutant $\mathrm{Cx} 26$ is an impaired $\mathrm{K}^{+}$transport by supporting cells rather than affecting endolymph homeostasis, as originally hypothesized. Since $C \times 26$ was not knocked out in the vestibule in the conditional model and its vestibular expression was normal in homozygous mice, these mice did not exhibit vestibular defects. However, no vestibular or other abnormalities were found in the second model as well. In addition, although the dominant mutant Cx26 R75W was expressed also in the cochlear connective tissue cell system, no obvious structural change was observed in the stria vascularis or spiral ligament (Cohen-Salmon et al., 2002; Kudo et al., 2003).

A Gjb6 knockout mouse model was also developed by insertion of a missense mutation. Homozygous mice were viable and fertile, but hearing impaired and lacked EP. Degeneration of the organ of Corti, due to apoptosis, was observed from the age of P18, similar to Gjb2 mutant mice (Teubner et al., 2003).

$\mathrm{C} \times 26$ and $\mathrm{C} \times 30$ co-assemble in the same gap junctions (Ahmad et al., 2003; Forge et al., 2003). Although Cx30 did not fail to form homomeric gap junctions in Cx26-deficient cells, Cx30 could not 
compensate for the lack of Cx26 in the conditional knockout model (Cohen-Salmon et al., 2002). Different connexins differ in size and ionic selectivity and have distinct voltage-gating sensitivities. As a result, connexons assembled from different connexins have different permeation and gating functions (Bruzzone and Cohen-Salmon, 2005; Zhao et al., 2006)]. Thus, characteristics of homomeric connexons, assembled from Cx30 only, may be different from those of heteromeric connexons assembled from both $\mathrm{Cx} 26$ and $\mathrm{C} \times 30$. Even if the permeation of small ions (like $\mathrm{K}^{+}$) is similar in different connexon types, the delivery of bigger secondary messenger molecules may be different, affecting $\mathrm{K}^{+}$ influxes indirectly. A recent paper offered that some Gjb2 mutations affect the gap junction permeability for inositol triphosphate rather than for $\mathrm{K}^{+}$. The failure to recycle $\mathrm{K}^{+}$from the supporting cells back to the endolymph was suggested to be secondary to inositol triphosphate transport (Beltramello et al., 2005). Nonetheless, the failure of $\mathrm{Cx} 30$ to compensate for Cx26 lack may result from its low expression. In the opposite case, over-expression of Cx26 in Gjb6 knockout mice completely restored hearing sensitivity and prevented hair cell degeneration. Thus, at least Cx26 can compensate for the absence of $\mathrm{C} \times 30$, suggesting that heteromeric gap junctions that contain both $\mathrm{C} \times 26$ and $\mathrm{C} \times 30$ are not essential for normal hearing and for organ of Corti survival in mice. Interestingly, Gjb6 knockout mice under-expressed Cx26 protein in the cochlea, suggesting an accelerated degradation of the homomeric gap junctions. Gjb6 knockout mice that also carried the gene for over-expression of Cx26, over-expressed Cx26 in the liver, but in the cochlea Cx26 levels were normal, suggesting that homomeric $\mathrm{C} \times 26$ gap junctions are less stable than heteromeric $\mathrm{C} \times 26-\mathrm{C} \times 30$ assemblies, but have a similar function (Ahmad et al., 2007).

Although connexin 29 (Cx29) is not involved in $\mathrm{K}^{+}$ions recycling in the cochlea, it is worth mentioning, since mutations in the GJE1/CX29gene were found in NSHL patients recently (Yang et al., 2007). The cochlear distribution of $C x 29$ is very different from that of $\mathrm{C} \times 26$ and $\mathrm{C} \times 30$. Unlike $\mathrm{C} \times 26$ and $\mathrm{C} \times 30$, which are mostly expressed in cochlear supporting cells and fibrocytes, Cx29 is expressed mainly in Schwann cells of the spiral ganglion and at lower abundance in the stria vascularis (Eiberger et al., 2006; Tang et al., 2006b). The expression of Cx29 in brain and other organs is also mainly in myelinating cells. Two groups created knockout Gje1 mice. While one group reported no abnormalities in Cx29-deficient C57BL/6 mice, including normal myelin sheets (Eiberger et al., 2006), the other group reported hearing loss due to severe demyelination at the soma of spiral ganglion neurons (neuropathy), with a penetrance of $\sim 50 \%$ and no damage to the inner ear neuroepithelium in BALB/c mice (Tang et al., 2006b).

Tight junctions, the most apical junctions in epithelial cells, serve as the major ion-selective barrier against paracellular transfer of fluids. In addition, they contribute to the maintenance of cellular polarity by forming an intramembrane barrier that restricts the lateral diffusion of apical and basolateral membrane components. Tight junctions are composed of at least three types of transmembrane proteins: occludin, claudins and members of the junction adhesion molecule (JAM) family. More than 20 claudins are known, each with a distinct permeability [recently reviewed in (Kondoh et al., 2006)]. In the cochlea, the essential separation of perilymph from endolymph is achieved by tight junctions that seal the spaces between the cells bordering the fluid compartments. Following the identification of recessive mutations of human CLDN14 as responsible for profound NSHL in humans (Wilcox et al., 2001), Cldn14-null mice were created to explore the role of claudin 14 in the inner ear. Claudin 14 was detected in tight junctions of the cochlea's reticular lamina (tight junctions between hair cells and supporting cells and between neighboring supporting cells). C/dn14-null mice had a normal EP, but were deaf. No vestibular phenotype was observed. Although the reticular lamina tight junctions seemed normal microscopically in Cldn14-null mice, the hair cell stereocilia were lost or disorganized during the first 3 weeks of life, rapidly followed by hair cell degeneration. $\mathrm{OHC}$ were degenerated before IHC. Since claudin 14 has a higher permeability to $\mathrm{K}^{+}$than $\mathrm{Na}^{+}$, it may be required to maintain the proper ionic composition of the perilymphatic fluid surrounding the basolateral surface of OHC. The accurate ionic composition of this fluid may be essential for $\mathrm{OHC}$ survival (Ben-Yosef et al., 2003).

The genes Kcne1, Kcnq 1 and Kcnq4 encode for subunits of slow voltage activated potassium channels, which are the major determinants of cellular repolarization in excitable cells. They open in response to depolarization and facilitate selective efflux of $\mathrm{K}^{+}$across the plasma membrane. Each channel is composed of four alpha and some beta subunits. While the pore-forming alpha subunits are sufficient to form functional channels, beta subunits determine the channel's unique properties, including its single-channel conductance, overall channel activity, voltage dependence, activation time dependence, temperature and $\mathrm{pH}$ sensitivity, as well as drug sensitivity [reviewed in (Wangemann, 2002)].

Stria vascularis marginal cells and vestibular dark cells secrete $\mathrm{K}^{+}$into the endolymph only by $\mathrm{K}^{+}$channels composed of Kcnq1 (alpha) and Kcne1 (beta) subunits. Therefore, Kcnq1/Kcne1 channels are responsible for endolymph formation (Marcus et al., 1997; Neyroud et al., 1997; Marcus et al., 1998; Nicolas et al., 2001). In cardiac myocytes, Kcnq $1 / \mathrm{Kcne} 1 \mathrm{~K}^{+}$channels carry the slowly activating rectifier $\mathrm{K}^{+}$current that plays a major role in the repolarization phase of the cardiac action potential. Therefore, mutations in KCNE1 or KCNQ1 in humans induce indistinguishable SHL phenotypes (Jervell and Lange-Nielsen Syndrome) of $\mathrm{HHL}$ and cardiac symptoms, including prolonged QT intervals and arrhythmias followed by syncope or sudden death (Neyroud et al., 1997; Schulze-Bahr et al., 1997; Tyson et al., 1997).

Kcne1 (Vetter et al., 1996; Nicolas et al., 2001) or Kcnq1 (Lee et al., 2000; Casimiro et al., 2001; Rivas and Francis, 2005) knockout mice exhibited a classic waltzer-like phenotype with severe hearing loss and vestibular symptoms, up to complete deafness in adult mice. Although the inner ear histology was normal at birth, changes developed later. The strial marginal cells and the vestibular dark cells were unable to secrete $\mathrm{K}^{+}$ions, leading to a secondary degeneration of the neuroepithelium including the hair cells and to collapse of the endolymphatic space. Similarly, the endolymphatic space is also collapsed in Jervell and Lange-Nielsen syndrome patients (Friedmann et al., 1966). At birth, the wild type mouse EP is very low, with high $\mathrm{Na}^{+}$ and low $\mathrm{K}^{+}$concentrations in the endolymph. After birth, the EP is increased gradually (in particular from P7), reaching the adult value at P14 (Yamasaki et al., 2000). Accordingly, Kcne1(Vetter et al., 1996) or Kcnq1 (Casimiro et al., 2001) knockout mice displayed normal endolymphatic spaces at birth. Only 3 days after 
birth, a collapse of the Reissner's membrane and a decrease in the endolymphatic space volume began to be detected. A spontaneous point mutation in Kcne 1 also arose in mice (punk rocker mice; Kcne $\left.{ }^{10 k}\right)$. Homozygous mice expressed a severely truncated Kcne1 protein and a similar phenotype to that of Kcne1 knockout mice (Letts et al., 2000). Kcnq1 knockout mice also exhibited cardiac repolarization defects (Casimiro et al., 2001; Casimiro et al., 2004). While Kcnq1 is the channel core, it appears that Kcne1 is required for its trafficking to the plasma membrane, since vestibular dark cells in Kcne1 knockout mice expressed Kcnq1 in their cytoplasm rather than in their apical membranes (Nicolas et al., 2001). Thus, Kcne1 seems to be essential for Kcnq1 membrane targeting and/or stability of Kcnq1 in the membrane.

Kcnq4 is an alpha subunit of an M-type $\mathrm{K}^{+}$channel. M-type channels are very slow voltage-dependent $\mathrm{K}^{+}$channels. In neurons, M-channels can oppose sustained membrane depolarization and repetitive firing of action potentials following a strong excitatory input, but they also can transiently elevate the neuron excitability following its exposure to modulatory neurotransmitters (Cooper and Jan, 2003). Accordingly, Kcnq4 channels were found in neurons of several nuclei of the central auditory pathway. However, Kcnq4 was also detected in the basolateral membrane of cochlear (Beisel et al., 2000) and vestibular (Rocha-Sanchez et al., 2007) mouse hair cells (both $\mathrm{OHC}$ and IHC). After the onset of hearing (P12-14), it localized exclusively to the basal pole. Therefore, it was suggested that Kcnq4 channels are responsible for the secretion of surplus $\mathrm{K}^{+}$ions from the hair cell to the perilymph surrounding its basolateral membrane and for setting the hair cell resting membrane potential (Kharkovets et al., 2000; Boettger et al., 2002; Beisel et al., 2005; Rocha-Sanchez et al., 2007). In humans, KCNQ4 mutations induce autosomal dominant $\mathrm{NSHL}$, suggesting that the mutated gene has a dominant negative effect when it is co-expressed with the wild type allele (Kubisch et al., 1999). Two mouse models with mutated Kcnq4 were developed: a homozygous knockout mouse and a knock-in mouse with a point mutation that imitates the dominant negative mutation in humans. No vestibular symptoms were observed in both mouse models, although Kcnq4 is strongly expressed in WT vestibular hair cells. The mice had normal hearing at postnatal stages, but displayed a progressive hearing loss that was accompanied with a progressive degeneration of $\mathrm{OHC}$. The progression of both deafness and $\mathrm{OHC}$ loss was faster in homozygous knockout and knock-in mice (weeks) compared to heterozygous knock-in mice (months). Using a selective inhibitor of Kcnq channels to isolate Kcnq-dependent $\mathrm{K}^{+}$currents, no Kcnq-dependent $\mathrm{K}^{+}$currents were detected in $\mathrm{OHC}$ from homozygous or dominant negative heterozygous mice, resulting in depolarized resting membrane potentials of the $\mathrm{OHC}$. IHC were not significantly affected. Therefore, it was proposed that Kcnq4 mutations induce a progressive $\mathrm{HHL}$ due to chronic depolarization of $\mathrm{OHC}$, leading to their degeneration (Kharkovets et al., 2006). Recently, Kcnq4 expression in $\mathrm{OHC}$ was found to be regulated by thyroid hormones. The thyroid hormone receptor TR $\alpha$ directly affected Kcnq4 expression during $\mathrm{OHC}$ final differentiation. In TR $\alpha 1$ knockout mice, Kcnq4 was expressed but abnormally distributed along both the basal and lateral membranes of the OHC (Winter et al., 2006).

The SLC26 (solute carrier protein 26) family of anion exchangers includes integral proteins with 10-12 transmembrane domains that can transport several anions, including chloride, iodide, sulfate, nitrate, bicarbonate, hydroxyl, oxalate and formate. Each member in this family has different affinity and specificity per each anion. Two members of the SLC26 have been linked with HHL in humans: SLC26A4/pendrin and SLC26A5/prestin. SLC26A4 mutations were associated with both SHL (Pendred syndrome) (Everett et al., 1997) and NSHL (Li et al., 1998; Usami et al., 1999), while SLC26A5 was associated only with NSHL (Liu et al., 2003).

Pendred Syndrome, first described in 1896 (Pendred, 1896), is characterized by sensorineural deafness and enlarged thyroid goiter with elevated iodine discharge after perchlorate administration. Most of the patients also display radiologically detectable structural malformations of the inner ear, the most common feature of which is an enlarged vestibular endolymphatic duct [reviewed in (Glaser, 2003)]. Enlarged endolymphatic ducts were also observed in some patients with NSHL due to mutations in SLC26A4 (Li et al., 1998; Usami et al., 1999). In heterologous expression systems, pendrin has been shown to transport iodide, chloride, formate and nitrate (Scott etal., 1999; Scott and Karniski, 2000). Using mice and rats, pendrin was found to be expressed on apical membranes of thyroid, kidney and inner ear cells. The absence of pendrin was proposed as directly responsible for the defective organification of iodide in Pendred patients. However, S/c26a4 knockout mice lack thyroid symptoms (Everett et al., 2001) and the exact role of pendrin in the thyroid is still not clear. In the mouse inner ear, pendrin was detected on apical membranes of cells covered the endolymphatic cavities, which are considered to have a role in endolymph homeostasis (Everett et al., 1999; Royaux et al., 2003; Yoshino et al., 2004). In addition, the cochlear expression of pendrin included also supporting cells of the organ of Corti (Claudius and Deiters' cells), as well as the spiral ligament and the spiral ganglion. Recently, a more sensitive approach (postembedding immunogold analysis under an electron microscope) revealed some pendrin expression also in $\mathrm{OHC}$ and $\mathrm{IHC}$, in particular in their apical membranes and stereocilia (Yoshino et al., 2006).

$S / c 26 a 4$ knockout mice ( $P d s^{-/}$) exhibited waltzer-like vestibular dysfunction and complete deafness. Their inner ears developed normally only until E15, two days after the beginning of pendrin expression in wild type mice. Thereafter, a severe dilatation of endolymphatic cavities was developed, both in cochlea and vestibule (Figure 2, K-L). This dilatation was proposed to be secondary to an altered osmotic condition and an increased volume of the endolymphatic fluid. During the second postnatal week, hair cells began to degenerate. In the vestibule, the otoconia and otoconial membranes were also destructed (Everett et al., 2001). After weaning, the strial vascularis marginal cells of $P d s^{-/}$mice displayed irregular shapes and sizes, resulting in a thinner stria vascularis. In adult $P d s^{/-}$mice, hyperpigmentation of strial vascularis cells preceded their degeneration, suggesting free radical damage. Functional experiments revealed that $P d s^{--}$mice gradually loss the EP, beginning at $\mathrm{P} 12$, before the normal onset of hearing. Nevertheless, the endolymphatic $\mathrm{K}^{+}$concentration and the expression of Kcnq1/Kcne1 channels were normal. Pendrin deficiency also abolished the expression of $\mathrm{Kcnj10} \mathrm{\textrm {K } ^ { + }}$ channels in strial intermediate cells, although the Kcnj10 mRNA was normally expressed (Royaux et al., 2003; Wangemann et al., 2004). Kcnj10 channels have a role in recycling $\mathrm{K}^{+}$ions across the 
basal cell barrier of the stria vascularis. Thus, pendrin may serve a role in maintaining the $\mathrm{EP}$ without affecting $\mathrm{K}^{+}$secretion from the stria vascularis marginal cells, but rather by affecting $\mathrm{K}^{+}$fluxes in intermediate cells. Kcnj10knockout mice did not generate an EP, but had a reduced endolymphatic volume and $\mathrm{K}^{+}$concentration (Marcus et al., 2002). Therefore, pendrin deficiency may have additional outcomes. Another role of pendrin was recently revealed both in cochlea (Wangemann et al., 2007) and vestibule (Nakaya et al., 2007). $\mathrm{Ca}^{2+}$ channels (Trpv5 and Trpv6) in vestibular and cochlear epithelial cells reabsorb calcium ions from the endolymph and are inhibited by a low $\mathrm{pH}$. In the cochlea, Trpv5 and Trpv 6 are expressed in the strial vascularis marginal cells and sulcus epithelial cells, respectively. These channels maintain the low $\mathrm{Ca}^{2+}$ concentration of the normal endolymph. Pendrin-knockout mice displayed lower $\mathrm{pH}$ and higher $\mathrm{Ca}^{2+}$ concentration in the endolymph, resulting in a reduced transepithelial potential in the utricle. The higher $\mathrm{Ca}^{2+}$ level in the endolymph may inhibit sensory transduction necessary for hearing and promote hair cell degeneration. Thus, in the inner ear, pendrin was proposed to function as a Cl$-/ \mathrm{HCO}_{3}{ }^{-}$that mediates secretion of alkaline $\mathrm{HCO}_{3}{ }^{-}$ ions to the endolymphatic space and one of its important roles may be to maintain the endolymph pH (Nakaya et al., 2007; Wangemann et al., 2007). The hyperpigmentation of stria vascularis in adult $P d s^{-}$mice raised the hypothesis that an inflammation process is involved in their degeneration. Indeed, this hyperpigmentation and marginal cell reorganization occurred concurrently with invasion of macrophages specifically to the stria vascularis and expression of macrophage and complement markers (Jabba et al., 2006). The winged helix/forkhead gene Foxi1 (also known as $F k h 10$ ) was proposed to induce pendrin expression, since Foxi1-null mice do not express pendrin and exhibit a similar phenotype to pendrin knockout mice (Hulander et al., 2003).

\section{SLC26A5/prestin - the motor protein of outer hair cell electromotility}

The mammalian cochlea presents two mechanisms for amplification of sound signals: (a) amplification of stereocilia motions by mechano-electric transducer channels (exists in all known auditory organs); and (b) OHC somatic electromotility - a voltagedependent rapid alteration of the length and stiffness of $\mathrm{OHC}$ (exists only in mammalian inner ears), termed also as the cochlear amplifier. Electromotility includes shortening of depolarized $\mathrm{OHC}$ and lengthening of hyperpolarized cells, independently on ATP or $\mathrm{OHC} \mathrm{Ca}{ }^{2+}$ level. Amplification by $\mathrm{OHC}$ electromotility is believed to amplify cochlear vibrations and enable the acute hearing sensitivity and frequency selectivity of the mammalian cochlea. This mechanism enables the cochlear response to low $(<1 \mathrm{KHz})$ frequency signals [recently reviewed in (Frolenkov, 2006)].

Prestin is an integral protein that is expressed only in the cochlear $\mathrm{OHC}$ (an $\mathrm{OHC}$ is illustrated in Figure 1D). Prestin molecules, both as monomers and tetramers, are abundantly expressed along the $\mathrm{OHC}$ lateral membrane and for a lesser extent - in the basal membrane. Developmental expression of prestin coincides with the appearance of electromotility (Belyantseva et al., 2000; Zheng et al., 2000; Yu et al., 2006). Although prestin belongs to the SLC26 family of anion exchang- ers and has a similar structure to other members of this family, clear evidence indicating that it functions as ion transporter has not reported yet. Moreover, a knock-out of prestin (S/c26a5) in mice did not affect whole-cell currents of OHC (Liberman et al., 2002). Instead, prestin is considered as the voltage-dependent motor protein responsible for $\mathrm{OHC}$ electromotility (Zheng et al., 2000), as S/c26a5knockout mice displayed no OHC electromotility (Figure 2M) and frequency selectivity. These mice support the hypothesis that $\mathrm{OHC}$ electromotility enhances the inner ear sensitivity, since they exhibited 40-60 dB loss of cochlear sensitivity with no disruption of $\mathrm{OHC}$ hair bundles and mechanoelectrical transduction. In addition, S/c26a5-null mice displayed shorter $\mathrm{OHC}$ (Figure $2 \mathrm{~N}$ ), which is not surprising, as prestin is very abundant in the lateral walls of these cells. At 4-9 weeks of age, a secondary apoptosis of $\mathrm{OHC}$ was observed in the cochlea's basal quarter in S/C26a5-null mice, followed by IHC degeneration, although IHC do not express prestin. However, the HI preceded hair cells degeneration by at least two weeks, implying that lack of electromotility was the primary reason for hearing loss (Liberman etal., 2002; Cheatham etal., 2004; Wu etal., 2004). Recently, the typical distribution of prestin along the $\mathrm{OHC}$ lateral membrane was found to depend on the thyroid hormone receptor TR $\beta$ (Winter et al., 2006). Although the absolute magnitude of $\mathrm{OHC}$ electromotility in heterozygous mice was about half of normal (Liberman etal., 2002), cochlear function and appearance in mice with only one copy of the S/c26a5gene were normal (Cheatham et al., 2005). It was suggested that prestin senses voltage by binding an intracellular $\mathrm{Cl}^{-}$ion in depolarized cells. As a result, its conformational is altered. Thus, prestin is a very efficient direct voltage-to-force converter. Its function is associated with a typical nonlinear capacitance, which may be measured [recently reviewed in (Dallos et al., 2006)].

\section{Unconventional myosins}

Unconventional myosins are motor molecules that contain an actin-binding domain in their $\mathrm{N}$-terminal motor or head domain. Using ATP as an energy source, they can move along actin filaments. Unconventional myosins also have binding sites for proteins on their C-terminal tails and thus, they may serve as "cars» that drag cargo proteins to their target sites in the cell. The mammalian inner ear expresses several unconventional myosins, each of which has a unique expression pattern and function in the inner ear. Mutations in five myosin genes (Myo1a, Myo3a, Myo6, Myo7a and Myo15a) have been associated with HHL in humans. The expression pattern of myosin $1 \mathrm{~A}$ in the mouse inner ear has not been studied yet. Myo3a, Myo6, Myo7a and Myo15a are expressed within the mouse inner ear only in hair cells, and have a role in hair bundle organization [recently reviewed in (Hertzano and Avraham, 2005)]. Two of them, myosins VIla and $\mathrm{XV}$, can bind the PDZ sites on harmonin or whirlin and are part of the Usher-related network that is illustrated in Figure $1 \mathrm{~F}$ [reviewed in (Reiners et al., 2006)]. Thus, myosin VIla (Boeda et al., 2002; Senften et al., 2006) and myosin XVa (Belyantseva et al., 2005) actively transport harmonin and whirlin, together with attached proteins, to the proper sites in the stereocilia. Recently, myosin IIla was also shown to be localized at stereocilia tips and required for their proper maintenance (Schneider et al., 2006).

Mouse models are available only with mutations in Myo6, 
Myo7a and Myo15a. Null mutations of Myo6 [Snell's waltzer (Avraham et al., 1995)], Myo7a [shaker1 (Self et al., 1998)] and Myo15a [shaker2 (Probst et al., 1998)] induced similar waltzerlike phenotypes in homozygotes (deafness and vestibular dysfunction), resulting from stereocilia fusion (Myo6), disorganization (Myo7a) or shortening (Myo15a). Myo6 and Myo7a null mice also displayed subsequent degeneration of the hair cell. While mice homozygous for null mutations in Myo6, Myo7a or Myo15a were deaf, heterozygotes displayed a normal phenotype. Moreover, doubly heterozygous mice for both Myo15a and another (Myo6or Myo7a) null allele were also normal (Karolyi etal., 2003). However, a missense Myo7a mutation (headbanger mice; Hdb) induced vestibular phenotype and mild $\mathrm{HI}$ also in heterozygotes (Figure 3D), resulted from elongation and fusion of hair cell stereocilia. Homozygotes presented a more severe phenotype (Rhodes et al., 2004). Myo6 will be reviewed in more details as an example.

A spontaneous mutation, Snell's waltzer (sv), arose in 1966 (Deol and Green, 1966). The circling behavior of Snell's waltzer mice is presented in Figure 3E. A radiation-induced mutation in the same locus is also available $\left(s e^{s v} / s e^{s y}\right.$ (Russell, 1971), as well as an ENU-generated mutant (ENU89) (personal communication, Colin Fletcher and Karen Avraham). A mutation in the Myo6 gene was found in the svallele (Avraham et al., 1995). In mice and zebrafish inner ears, myosin VI is expressed specifically in apical plasma membrane of hair cells, near the stereocilia base (Self et al., 1999; Kappler et al., 2004). Homozygous sv mice exhibited a progressive degeneration of inner ear hair cells from $\mathrm{P} 12$, leading to degeneration of the entire neuroepithelium of the inner ear. Early stages of hair cells and stereocilia development were normal, since at birth only part of the hair bundles were disorganized. However, during the first postnatal week, hair bundles were progressively disorganized and the hair cell apical plasma membrane was raised. Thereafter, during the following two weeks, stereocilia were abnormally fused together to form giant non-functional stereocilia (Self et al., 1999; Kappler et al., 2004). A similar phenotype was observed in zebrafish with mutations in the Myo6bgene. In zebrafish, the Myo6gene is duplicated (Myo6a and Myo6b) and only Myo6bis predominantly expressed in the inner ear and lateral line neuroepithelium. Similar to $s \mathrm{v}$ mice, mutations in the zebrafish Myo6b are responsible for auditory and vestibular defects (satellitemutants) due to disorganized hair bundles in which the stereocilia are eventually fused. Structural defects at the apical plasma membrane were observed as well and large vesicles were accumulated near the cuticular plate (Seiler et al., 2004). Based on zebrafish satelliteand mouse sv mutants, it was suggested that myosin VI anchors the apical plasma membrane of the stereocilium to the core actin filaments (Figure 1F). In the absence of myosin VI, the apical plasma membrane pulled up above the epithelium and between the stereocilia, leading to stereocilia fusion. Mutations in the human MYO6gene were linked with $\mathrm{HHL}$ in humans only six years after the identification of Myo6 mutations in sv mice. While in mice Myo6 mutations were associated only with recessive NSHL, human MYO6 mutations were linked both with dominant (Melchionda et al., 2001) and recessive NSHL (Ahmed et al., 2003), as well as with dominant SHL that includes cardiac hypertrophy and prolonged QT in addition to sensorineural $\mathrm{HHL}$ (Mohiddin et al., 2004).

\section{Hair cell genes for transcription factors}

Sensory hair cells and non-sensory supporting cells in the inner ear neuroepithelium arise from a common progenitor. The

TABLE 2

GENES THAT WERE LINKED WITH HUMAN HHL AND CLONED, BUT HAVE NO MUTANT MOUSE MODEL THUS FAR

\begin{tabular}{|c|c|c|c|c|c|}
\hline & Gene name & Full name & $\begin{array}{c}\text { Year of first linkage } \\
\text { of the gene to } \mathrm{HHL} \text { in humans }\end{array}$ & Gene cloning in humans - first reference & Human syndrome \\
\hline 1 & COLAA4 & collagen type IV, alpha 4 chain & 1994 & (Mochizuki et al., 1994) & Alport \\
\hline 2 & COL4A5 & collagen type IV, alpha 5 chain & 1994 & (Barker et al., 1990) & Alport \\
\hline 3 & TIMM8A & $\begin{array}{l}\text { translocase of inner mitochondrial } \\
\text { membrane } 8 \text { homolog A (yeast) }\end{array}$ & 1995 & (Jin et al., 1996) & NS \\
\hline 4 & USH3A & Usher syndrome 2A / clarin-1 & 1995 & (Joensuu et al., 2001) & Usher \\
\hline 5 & $\operatorname{TCOF1}\left(^{*}\right)$ & Treacher Collins-Franceschetti syndrome 1 & 1996 & (Dixon et al., 1996) & Treacher Collins \\
\hline 6 & DIAPH1 & diaphanous 1 & 1997 & (Lynch et al., 1997) & NS \\
\hline 7 & $D S P P$ & dentin sialophosphoprotein & 2001 & (Xiao et al., 2001) & NS \\
\hline 8 & EYA4 & eyes absent homolog 4 (Drosophila) & 2001 & (Wayne et al., 2001) & NS \\
\hline 9 & STRC & stereocilin & 2001 & (Verpy et al., 2001) & NS \\
\hline 10 & TMPRSS3 & transmembrane protease, serine 3 & 2001 & (Scott et al., 2001) & NS \\
\hline 11 & WFS1 & Wolfram syndrome $1 /$ wolframin & 2001 & (Bespalova et al., 2001; Young et al., 2001) & Wolfram and NS \\
\hline 12 & МУОЗА & myosin IIIA & 2002 & (Walsh et al., 2002) & NS \\
\hline 13 & OTOA & otoancorin & 2002 & (Zwaenepoel et al., 2002) & NS \\
\hline 14 & TFCP2L3 / GRHL2 & grainyhead-like 2 (Drosophila) & 2002 & (Peters et al., 2002) & NS \\
\hline 15 & ACTG1 & actin, gamma 1 & 2003 & (van Wijk et al., 2003; Zhu et al., 2003) & NS \\
\hline 16 & MYO1A & myosin $1 \mathrm{~A}$ & 2003 & (Donaudy et al., 2003) & NS \\
\hline 17 & MYH14 & non-muscle myosin, heavy chain 14 & 2004 & (Donaudy et al., 2004) & NS \\
\hline 18 & $T R I O B P$ & TRIO and F-actin binding protein & 2006 & (Riazuddin et al., 2006; Shahin et al., 2006) & NS \\
\hline
\end{tabular}

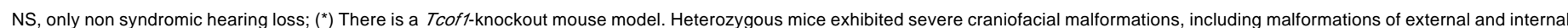
ear, and died at birth (Dixon et al., 2000; Dixon et al., 2006). However, the effect Tcof1 haploinsufficiency on the mice inner ears has not been reported. 
prosensory progenitor cells differentiate to hair cells by default, but this differentiation decision is generally inhibited by Notch signaling (Yamamoto et al., 2006). Notch activation laterally represses expression of the Math1/Atoh1 transcription factor, which is required, together with Sox2 (described below), to induce differentiation of prosensory progenitor cells to hair cells. Indeed, Atoh1 knockout mice have no hair cells in their vestibules and cochleae (Bermingham et al., 1999; Yamamoto et al., 2006).

Many additional transcription factors are crucial for inner ear development. Some of them are expressed specifically in the inner ear hair cells (e.g. Pou4f3) and others are crucial for the development of other organs as well. Several transcription factors have been correlated with deafness both in humans and mice (Eya1, Pou3f4, Pou4f3, Mitf, Pax3, Snai2/Slug, Sox2, Sox10, Six 1; see Supplementary Table S1). Sox2 and Pou4f3 will be described here as examples.

SOX2mutations in humans are correlated mainly with bilateral anophthalmia (eye malformations) in heterozygotes (Fantes et al., 2003). However, two de novo SOX2 mutations have been correlated with SHL in heterozygotes. A nonsense mutation (Q155X) was suggested to be responsible for $\mathrm{HI}$, in addition to anophthalmia, absence of all optic pathways and other neurological abnormalities (Hagstrom et al., 2005); and a missense mutation (479delA) was suggested to be responsible for a syndrome combining congenital hypothalamo-pituitary disorder and $\mathrm{HI}$ (Kelberman et al., 2006). In mouse embryos, Sox2 is expressed mainly in the developing CNS and sensory placodes, where it plays critical roles in embryogenesis. At E9.5, Sox2 is expressed not only in the neural tube but also in the otocyst, from which the inner ear neuroepithelium will be developed. In the developing cochlea, Sox2is normally expressed only in prosensory progenitor cells, as well as in differentiated hair cells and supporting cells in the developing organ of Corti (Wood and Episkopou, 1999; Kiernan et al., 2005). Two mutated Sox2 alleles, Lcc (light coat and circling) and $Y_{s b}$ (yellow submarine), were generated in mice by coincidental mutagenesis, using $X$-ray radiation or transgene insertion, respectively. Mice carrying the mutated alleles could be easily identified, due to a semi-dominant yellow coat color. The $L c c$ and $Y s b$ alleles contained intact coding and nearby sequences of Sox2, but regulatory elements that affect Sox2 expression were mutated (the inserted sequence used to raise the $Y s b$ allele contained a regulatory sequence from the Col2a1 gene). As a result, $L c c$ and $Y s b$ homozygous E9.5 mouse embryos expressed normal Sox2 in the neural tube but no ( $L C C)$ or less $\left(Y_{s} b\right)$ Sox2in the otocyst. Thus, the mutations did not disturb brain development, inducing milder phenotypes compared to SOX2 mutations that have been reported in humans. Homozygous mice exhibited a severe $\mathrm{HI}$ ( $Y s b$ mice) or complete deafness ( $L c c$ mice), as well as circling behavior, due to malformation of the inner ear and its neuroepithelium. The vestibule was more severely affected. At birth, Lccmice, which did not express Sox2in their inner ears, displayed more severely malformed inner ears and the neuroepithelium was completely absent, since both hair cells and supporting cells failed to differentiate. $Y_{s} b$ homozygotes, which expressed a low level of Sox2 in the inner ear, exhibited almost no hair cells in their vestibule. In the basal region of the cochlea, Ysbhomozygotes displayed abnormal patches of disorganized hair cells, with regions containing no hair cells between them (Figure 2, G-J). The apical region of their cochleae included disorganized hair cells with no clear delineation of IHC and $\mathrm{OHC}$. The unique pattern of hair cells development in $Y_{s} b$ mice may result from the inserted Col2a 1 regulatory motif to the regulatory sequence of Sox2. Lcchomozygotes, that exhibited no Sox2 expression in the inner ear, did not express Atoh1 either, while $Y_{s} b$ homozygotes that expressed some Sox2 also expressed Atoh1. Therefore, Sox2 was suggested to act upstream to Atoh1 (Dong et al., 2002; Kiernan et al., 2005).

POU-domain transcription factor genes are known as controlling terminal stages of central nervous system (CNS) development [reviewed in (Ryan and Rosenfeld, 1997)]. In mice, Pou4f3 (also known as Brn-3cor Brn3. 1) is expressed quite specifically in cochlear (Figure 20) and vestibular hair cells. Its expression may be detected in inner ear hair cells from E12.5, after Atoh1 expression and is gradually increased until birth (Xiang et al., 1998; Hertzano et al., 2004). A POU4F3mutation has been linked to autosomal dominant progressive NSHL in humans (Vahava et al., 1998). Pou4f3-knockout mice (Erkman et al., 1996; Xiang et al., 1997), as well as dreidel (dd) mice that do not express a functional Pou4f3 (Hertzano et al., 2004), displayed a similar waltzer-like phenotype of profound deafness (Figure 3, A-B) and vestibular dysfunction, including head tossing, circling behavior and hyperactivity. Pou4f3-knockout mice exhibited a progressive loss of inner ear hair cells both in the vestibule and cochlea that led to a secondary degeneration of supporting cells, as well as degeneration of spiral and vestibular ganglion neurons. Pou $4 \mathrm{f} 3$ is expressed in postmitotic prosensory progenitor cells that are committed to develop to hair cells, but not in the pre-commitment mitotic cells. Hair cells in the developing inner ears of Pou4f3 knockout mice underwent initial differentiation, but failed to form mature stereocilia, some of the hair cells were mislocalized to the supporting cell layer and all or most of them were degenerated by apoptosis during late gestation and early postnatal days. Thus, Pou4f 3 is crucial for normal terminal differentiation, migration and survival of the inner ear hair cells (Erkman et al., 1996; Xiang et al., 1997; Xiang et al., 1998). The Gfi1 and $L h x 3$ transcription factor genes were suggested as targets of Pou4f3. Homozygous dreidel mice expressed a minimal level of Gfi1 mRNA in both cochlear and vestibular hair cells (Figure 2P) and did not express Lhx3 in cochlear hair cells (Figure 2, S-V) (Hertzano et al., 2007).

\section{Deaf mouse mutants not correlated with human heredi- tary hearing loss}

Mutant mouse models have not been developed yet for all the genes that had been linked with human HHL. From 61 cloned genes that have been associated with human HHL (Van Camp and Smith, 2006), 18 have no mouse model thus far (Table 2). As mentioned in the introduction, $75 \%$ of the genes that have been linked with inner ear malformations or dysfunction in mice (Jackson_Laboratory, 2007) have not been linked with HHL in humans yet (Van Camp and Smith, 2006). Products of some of these genes may interact with already known deafness-related networks. For example, the lysosomal membrane protein Scarb2/ LIMP-2, which regulates membrane transport of some proteins, was found to be essential for localization of Kcnq1/Kcne1 potassium channels in the apical membrane of stria vascularis marginal cells and vestibular dark cells of adult mice. As a result, Scarb2deficient mice displayed a progressive hearing loss due to degen- 
eration of the stria vascularis (Knipper et al., 2006).

Other genes that have been linked with $\mathrm{HI}$ in knockout mice represent product classes that have not been related yet to $\mathrm{HHL}$ in humans and yet are crucial for inner ear function. For example, creatine kinase (Ckb) may have a role in ATP transfer to stereociliar ATPases. Ckbknockout mice display $\mathrm{HI}$ and vestibular dysfunction. The cytosolic brain isoform of creatine kinase is the most abundant protein after $\beta$-actin in the avian utricle hair bundle, as discovered using mass spectrometry (Shin et al., 2007).

Another recent example is a spontaneous mutation (jbg) that led to $\mathrm{HI}$ and vestibular dysfunction in the jitterbug mice and was mapped to the Clic5gene. Clic5 belongs to the chloride intracellular channels family. In the mouse inner ear, it was detected specifically in the basal region of stereocilia in both cochlear and vestibular hair cells. Jitterbug mice exhibited aberrant stereocilia and progressive hair cell degeneration, suggesting that Clic5 may have a role in assembly or maintenance of stereocilia. Clic5 appeared to associate with radixin in stereocilia bases and was suggested to participate in formation or stabilization of connections between the stereociliar plasma membrane and its actin core (Gagnon et al., 2006).

The same mutation may induce different phenotypes in different inbred mouse strains that express different genetic modifiers. Such modifiers were also reported in humans [the first was the DFNM1 locus (Riazuddin et al., 2000)]. In mice, this phenomenon in known as the strain background effect. For example, mdfwand $A h / a l l e l e s$ of the Cdh23gene can induce age-related and noiseinduced hearing loss in homozygotes in several mouse strains (with different onset times in different strains), but other strains are relatively resistance for these mutations (Zheng and Johnson, 2001; Noben-Trauth et al., 2003). Mutated alleles of Cdh23may act as genetic modifiers in heterozygotes. Thus, the Ah/allele may

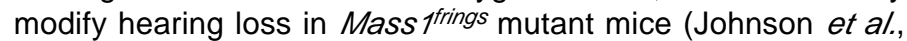
2005). At least an additional seven loci may induce age-related hearing loss in mice. In digenic mouse mutants, who carry two mutated genes and display a different phenotype compared to mice homozygous for a mutation in one of these genes, one of the mutated genes may be considered as a genetic modifier [e.g. (Adato et al., 1999; Johnson et al., 2005; Zheng et al., 2005)]. In order to identify such modifiers, some groups mated mice carrying deafness-related mutations with mice from different strains [e.g. (Asher et al., 1996; Niu et al., 2006)]. This subject was recently reviewed (Johnson et al., 2006).

\section{Summary}

Efforts are now underway to create knock-outs and conditional mutants for every gene in the mouse genome [NIH knockout mouse project, (KOMP): http://www.nih.gov/science/models/ mouse/knockout/; and European conditional mouse mutagenesis program (EUCOMM): http://www.eucomm.org/]. This endeavor will undoubtedly create many more mouse models for human HHL. As discussed above, there have been many cases where the mouse gene has led to the discovery of the human $\mathrm{HI}$ gene (and vice versa), emphasizing the complementarity of mouse and human studies in the auditory and vestibular systems. Complex hearing impairment, which includes both noise-induced hearing loss and age-related hearing loss (presbyacusis), as well as the identification of modifiers, will require additional mouse models.
The identity of a human mutation is critical for human diagnostics and genetic counseling, and early identification and intervention is beneficial for hearing impaired patients (White, 2004; Hyde, 2005). The information acquired from mouse morphological and physiological studies, as exemplified from the various techniques in Figure 2, demonstrates that the study of mouse models for deafness will undoubtedly provide a key to understand auditory function and help develop critical elements for therapeutics (Atar and Avraham, 2005; Tang et al., 2006a).

\section{Acknowledgments}

We thank the following for providing us with figures: Ayala Lagziel, Doris Wu, Amy Kiernan, Ronna Hertzano, Jian Zuo, Richard Goodyear and Martine Cohen-Salmon. Research in the K.B.A. laboratory is supported by NIH grant R01 DC005641, The German-Israeli Foundation for Scientific Research and Development (GIF), the US-Israel Binational Science Foundation (BSF) Grant 2003335 and the European Commission FPG Integrated Projects EUROHEAR LSHG-CT-20054-512063 and EUMODIC 037188.

\section{References}

ABE, S., KATAGIRI, T., SAITO-HISAMINATO, A., USAMI, S., INOUE, Y., TSUNODA, T. and NAKAMURA, Y. (2003). Identification of CRYM as a candidate responsible for nonsyndromic deafness, through cDNA microarray analysis of human cochlear and vestibular tissues. Am. J. Hum. Genet. 72: 73-82.

ADATO, A., KALINSKI, H., WEIL, D., CHAIB, H., KOROSTISHEVSKY, M. and BONNE-TAMIR, B. (1999). Possible interaction between USH1B and USH3 gene products as implied by apparent digenic deafness inheritance. $A m$. J. Hum. Genet. 65: 261-265.

AdATO, A., LEFEVRE, G., DELPRAT, B., MICHEL, V., MICHALSKI, N., CHARDENOUX, S., WEIL, D., EL-AMRAOUI, A. and PETIT, C. (2005a). Usherin, the defective protein in Usher syndrome type IIA, is likely to be a component of interstereocilia ankle links in the inner ear sensory cells. Hum. Mol. Genet. 14: 3921-3932.

ADATO, A., MICHEL, V., KIKKAWA, Y., REINERS, J., ALAGRAMAM, K.N., WEIL, D., YONEKAWA, H., WOLFRUM, U., EL-AMRAOUI, A. and PETIT, C. (2005b). Interactions in the network of Usher syndrome type 1 proteins. Hum. Mol. Genet. 14: 347-356.

AHMAD, S., CHEN, S., SUN, J. and LIN, X. (2003). Connexins 26 and 30 are coassembled to form gap junctions in the cochlea of mice. Biochem. Biophys. Res. Commun. 307: 362-368.

AHMAD, S., TANG, W., CHANG, Q., QU, Y., HIBSHMAN, J., LI, Y., SOHL, G., WILLECKE, K., CHEN, P. and LIN, X. (2007). Restoration of connexin26 protein level in the cochlea completely rescues hearing in a mouse model of human connexin30-linked deafness. Proc Natl. Acad. Sci. USA 104: 1337-1341.

AHMED, Z.M., GOODYEAR, R., RIAZUDDIN, S., LAGZIEL, A., LEGAN, P.K., BEHRA, M., BURGESS, S.M., LILLEY, K.S., WILCOX, E.R., RIAZUDDIN, S. et al. (2006). The tip-link antigen, a protein associated with the transduction complex of sensory hair cells, is protocadherin-15. J. Neurosci. 26: 7022-7034.

AHMED, Z.M., MORELL, R.J., RIAZUDDIN, S., GROPMAN, A., SHAUKAT, S., AHMAD, M.M., MOHIDDIN, S.A., FANANAPAZIR, L., CARUSO, R.C., HUSNAIN, T. et al. (2003). Mutations of MYO6 are associated with recessive deafness, DFNB37. Am. J. Hum. Genet. 72: 1315-1322.

ALAGRAMAM, K.N., KWON, H.Y., CACHEIRO, N.L., STUBBS, L., WRIGHT, C.G., ERWAY, L.C. and WOYCHIK, R.P. (1999). A new mouse insertional mutation that causes sensorineural deafness and vestibular defects. Genetics 152: 1691-1699.

ALAGRAMAM, K.N., MURCIA, C.L., KWON, H.Y., PAWLOWSKI, K.S., WRIGHT, C.G. and WOYCHIK, R.P. (2001a). The mouse Ames waltzer hearing-loss mutant is caused by mutation of Pcdh15, a novel protocadherin gene. Nat. Genet. 27: 99-102.

ALAGRAMAM, K.N., STAHL, J.S., JONES, S.M., PAWLOWSKI, K.S. and WRIGHT, C.G. (2005). Characterization of vestibular dysfunction in the mouse model for Usher syndrome 1F. J. Assoc. Res. Otolaryngol. 6: 106-118. 
ALAGRAMAM, K.N., YUAN, H., KUEHN, M.H., MURCIA, C.L., WAYNE, S., SRISAILPATHY, C.R., LOWRY, R.B., KNAUS, R., VAN LAER, L., BERNIER, F.P. et al. (2001b). Mutations in the novel protocadherin PCDH15 cause Usher syndrome type 1F. Hum. Mol. Genet. 10: 1709-1718.

ALPORT, A.C. (1927). Hereditary familial congenital haemorrhagic nephritis. Brit. Med. J. 1: 504-506.

ASAMURA, K., ABE, S., IMAMURA, Y., ASZODI, A., SUZUKI, N., HASHIMOTO, S., TAKUMI, Y., HAYASHI, T., FASSLER, R., NAKAMURA, Y. et al. (2005). Type IX collagen is crucial for normal hearing. Neuroscience 132: 493-500.

ASHER, J.H., JR., HARRISON, R.W., MORELL, R., CAREY, M.L. and FRIEDMAN, T.B. (1996). Effects of Pax3 modifier genes on craniofacial morphology, pigmentation and viability: a murine model of Waardenburg syndrome variation. Genomics 34: 285-298.

ATAR, O. and AVRAHAM, K.B. (2005). Therapeutics of hearing loss: expectations vs reality. Drug Discov. Today 10: 1323-1330.

AVRAHAM, K.B., HASSON, T., STEEL, K.P., KINGSLEY, D.M., RUSSELL, L.B., MOOSEKER, M.S., COPELAND, N.G. and JENKINS, N.A. (1995). The mouse Snell's waltzer deafness gene encodes an unconventional myosin required for structural integrity of inner ear hair cells. Nat. Genet. 11: 369-375.

BALLANA, E., VENTAYOL, M., RABIONET, R., GASPARINI, P. and ESTIVILL, X. (2007). Connexins and deafness Homepage: http://davinci.crg.es/deafness/

BARKER, D.F., HOSTIKKA, S.L., ZHOU, J., CHOW, L.T., OLIPHANT, A.R., GERKEN, S.C., GREGORY, M.C., SKOLNICK, M.H., ATKIN, C.L. and TRYGGVASON, K. (1990). Identification of mutations in the COL4A5 collagen gene in Alport syndrome. Science 248: 1224-1227.

BEISEL, K.W., NELSON, N.C., DELIMONT, D.C. and FRITZSCH, B. (2000). Longitudinal gradients of KCNQ4 expression in spiral ganglion and cochlear hair cells correlate with progressive hearing loss in DFNA2. Brain Res. Mol. Brain Res. 82: 137-149.

BEISEL, K.W., ROCHA-SANCHEZ, S.M., MORRIS, K.A., NIE, L., FENG, F., KACHAR, B., YAMOAH, E.N. and FRITZSCH, B. (2005). Differential expression of KCNQ4 in inner hair cells and sensory neurons is the basis of progressive high-frequency hearing loss. J. Neurosci. 25: 9285-9293.

BELTRAMELLO, M., PIAZZA, V., BUKAUSKAS, F.F., POZZAN, T. and MAMMANO, F. (2005). Impaired permeability to Ins $(1,4,5) P 3$ in a mutant connexin underlies recessive hereditary deafness. Nat. Cell Biol. 7: 63-69.

BELYANTSEVA, I.A., ADLER, H.J., CURI, R., FROLENKOV, G.I. and KACHAR, B. (2000). Expression and localization of prestin and the sugar transporter GLUT5 during development of electromotility in cochlear outer hair cells. J. Neurosci. 20: RC116.

BELYANTSEVA, I.A., BOGER, E.T., NAZ, S., FROLENKOV, G.I., SELLERS, J.R., AHMED, Z.M., GRIFFITH, A.J. and FRIEDMAN, T.B. (2005). Myosin-XVa is required for tip localization of whirlin and differential elongation of hair-cell stereocilia. Nat. Cell Biol. 7: 148-156.

BEN-YOSEF, T., BELYANTSEVA, I.A., SAUNDERS, T.L., HUGHES, E.D., KAWAMOTO, K., VAN ITALLIE, C.M., BEYER, L.A., HALSEY, K., GARDNER, D.J., WILCOX, E.R. et al. (2003). Claudin 14 knockout mice, a model for autosomal recessive deafness DFNB29, are deaf due to cochlear hair cell degeneration. Hum. Mol. Genet. 12: 2049-2061.

BERGGREN, D., FRENZ, D., GALINOVIC-SCHWARTZ, V. and VAN DE WATER, T.R. (1997). Fine structure of extracellular matrix and basal laminae in two types of abnormal collagen production: L-proline analog-treated otocyst cultures and disproportionate micromelia (Dmm/Dmm) mutants. Hear. Res. 107: 125-135.

BERMINGHAM, N.A., HASSAN, B.A., PRICE, S.D., VOLLRATH, M.A., BEN-ARIE, N., EATOCK, R.A., BELLEN, H.J., LYSAKOWSKI, A. and ZOGHBI, H.Y. (1999). Math1: an essential gene for the generation of inner ear hair cells. Science 284: 1837-1841.

BESPALOVA, I.N., VAN CAMP, G., BOM, S.J., BROWN, D.J., CRYNS, K., DEWAN, A.T., ERSON, A.E., FLOTHMANN, K., KUNST, H.P., KURNOOL, P. et al. (2001). Mutations in the Wolfram syndrome 1 gene (WFS1) are a common cause of low frequency sensorineural hearing loss. Hum. Mol. Genet. 10: 25012508.

BISSONNETTE, J.P. and FEKETE, D.M. (1996). Standard atlas of the gross anatomy of the developing inner ear of the chicken. J. Comp. Neurol. 368: 620630.

BOedA, B., El-AMraOUI, A., BAHLOUL, A., GOOdYeAR, R., DAVIET, L.,
BLANCHARD, S., PERFETTINI, I., FATH, K.R., SHORTE, S., REINERS, J. et al. (2002). Myosin VIla, harmonin and cadherin 23, three Usher I gene products that cooperate to shape the sensory hair cell bundle. Embo J21: 6689-6699.

BOETTGER, T., HUBNER, C.A., MAIER, H., RUST, M.B., BECK, F.X. and JENTSCH, T.J. (2002). Deafness and renal tubular acidosis in mice lacking the $\mathrm{K}-\mathrm{Cl}$ cotransporter Kcc4. Nature 416: 874-878.

BROWN, K.S., CRANLEY, R.E., GREENE, R., KLEINMAN, H.K. and PENNYPACKER, J.P. (1981). Disproportionate micromelia (Dmm): an incomplete dominant mouse dwarfism with abnormal cartilage matrix. J. Embryol. Exp. Morphol. 62: 165-182.

BRUZZONE, R. and COHEN-SALMON, M. (2005). Hearing the messenger: Ins(1,4,5)P3 and deafness. Nat. Cell. Biol. 7: 14-16.

BRYDA, E.C., KIM, H.J., LEGARE, M.E., FRANKEL, W.N. and NOBEN-TRAUTH, K. (2001). High-resolution genetic and physical mapping of modifier-ofdeafwaddler (mdfw) and Waltzer (Cdh23v). Genomics 73: 338-342.

BRYDA, E.C., LING, H. and FLAHERTY, L. (1997). A high-resolution genetic map around waltzer on mouse chromosome 10 and identification of a new allele of waltzer. Mamm. Genome 8: 1-4.

BUNIELLO, A., MONTANARO, D., VOLINIA, S., GASPARINI, P. and MARIGO, V. (2004). An expression atlas of connexin genes in the mouse. Genomics 83: 812820.

CASIMIRO, M.C., KNOLLMANN, B.C., EBERT, S.N., VARY, J.C., JR., GREENE, A.E., FRANZ, M.R., GRINBERG, A., HUANG, S.P. and PFEIFER, K. (2001). Targeted disruption of the Kcnq1 gene produces a mouse model of Jervell and Lange-Nielsen Syndrome. Proc. Natl. Acad. Sci. USA 98: 2526-2531.

CASIMIRO, M.C., KNOLLMANN, B.C., YAMOAH, E.N., NIE, L., VARY, J.C., JR., SIRENKO, S.G., GREENE, A.E., GRINBERG, A., HUANG, S.P., EBERT, S.N. etal. (2004). Targeted point mutagenesis of mouse Kcnq1: phenotypic analysis of mice with point mutations that cause Romano-Ward syndrome in humans Genomics 84: 555-564.

CHEATHAM, M.A., HUYNH, K.H., GAO, J., ZUO, J. and DALLOS, P. (2004) Cochlear function in Prestin knockout mice. J. Physiol. 560: 821-830.

CHEATHAM, M.A., ZHENG, J., HUYNH, K.H., DU, G.G., GAO, J., ZUO, J., NAVARRETE, E. and DALLOS, P. (2005). Cochlear function in mice with only one copy of the prestin gene. J. Physiol. 569: 229-241.

CHO, H., YAMADA, Y. and YOO, T.J. (1991). Ultrastructural changes of cochlea in mice with hereditary chondrodysplasia (cho/cho). Ann. N. Y. Acad. Sci. 630: 259-261.

COGHILL, E.L., HUGILL, A., PARKINSON, N., DAVISON, C., GLENISTER, P., CLEMENTS, S., HUNTER, J., COX, R.D. and BROWN, S.D. (2002). A genedriven approach to the identification of ENU mutants in the mouse. Nat. Genet. 30: 255-256.

COHEN-SALMON, M., OTT, T., MICHEL, V., HARDELIN, J.P., PERFETTINI, I., EYBALIN, M., WU, T., MARCUS, D.C., WANGEMANN, P., WILLECKE, K. et al. (2002). Targeted ablation of connexin26 in the inner ear epithelial gap junction network causes hearing impairment and cell death. Curr. Biol. 12: 1106-1111.

COOPER, E.C. and JAN, L.Y. (2003). M-channels: neurological diseases, neuromodulation and drug development. Arch. Neurol. 60: 496-500.

COSGROVE, D., MEEHAN, D.T., GRUNKEMEYER, J.A., KORNAK, J.M., SAYERS, R., HUNTER, W.J. and SAMUELSON, G.C. (1996). Collagen COL4A3 knockout: a mouse model for autosomal Alport syndrome. Genes Dev. 10: 2981-2992.

COSGROVE, D., SAMUELSON, G., MEEHAN, D.T., MILLER, C., MCGEE, J., WALSH, E.J. and SIEGEL, M. (1998). Ultrastructural, physiological and molecular defects in the inner ear of a gene-knockout mouse model for autosomal Alport syndrome. Hear. Res. 121: 84-98.

CRAMER, L.P. (2000). Myosin VI: roles for a minus end-directed actin motor in cells. J. Cell Biol. 150: F121-126.

DALLOS, P., ZHENG, J. and CHEATHAM, M.A. (2006). Prestin and the cochlear amplifier. J. Physiol. 576: 37-42.

DAVIS, R.R., NEWLANDER, J.K., LING, X., CORTOPASSI, G.A., KRIEG, E.F. and ERWAY, L.C. (2001). Genetic basis for susceptibility to noise-induced hearing loss in mice. Hear. Res. 155: 82-90.

DENMAN-JOHNSON, K. and FORGE, A. (1999). Establishment of hair bundle polarity and orientation in the developing vestibular system of the mouse. J. Neurocytol. 28: 821-835. 
DEOL, M.S. (1956). The anatomy and development of the mutants pirouette, shaker-1 and waltzer in the mouse. Proc. R. Soc. Lond. B. Biol. Sci. 145: 206213.

DEOL, M.S. and GREEN, M.C. (1966). Snell's waltzer, a new mutation affecting behaviour and the inner ear in the mouse. Genet. Res. 8: 339-345.

DESIR, J., MOYA, G., REISH, O., VAN REGEMORTER, N., DECONINCK, H., DAVID, K.L., MEIRE, F.M. and ABRAMOWICZ, M.J. (2007). Borate transporter SLC4A11 mutations cause both Harboyan syndrome and non-syndromic corneal endothelial dystrophy. J. Med. Genet. 44: 322-326.

DI PALMA, F., HOLME, R.H., BRYDA, E.C., BELYANTSEVA, I.A., PELLEGRINO, R., KACHAR, B., STEEL, K.P. and NOBEN-TRAUTH, K. (2001a). Mutations in Cdh23, encoding a new type of cadherin, cause stereocilia disorganization in waltzer, the mouse model for Usher syndrome type 1D. Nat. Genet. 27: 103 107.

DI PALMA, F., PELLEGRINO, R. and NOBEN-TRAUTH, K. (2001b). Genomic structure, alternative splice forms and normal and mutant alleles of cadherin 23 (Cdh23). Gene 281: 31-41.

DIXON, J., BRAKEBUSCH, C., FASSLER, R. and DIXON, M.J. (2000). Increased levels of apoptosis in the prefusion neural folds underlie the craniofacial disorder, Treacher Collins syndrome. Hum. Mol. Genet. 9: 1473-1480.

DIXON, J., EDWARDS, S.J., GLADWIN, A.J., DIXON, M.J., LOFTUS, S.K., BONNER, C.A., KOPRIVNIKAR, K. and WASMUTH, J.J. (1996). Positional cloning of a gene involved in the pathogenesis of Treacher Collins syndrome. The Treacher Collins Syndrome Collaborative Group. Nat. Genet. 12: 130-136.

DIXON, J., JONES, N.C., SANDELL, L.L., JAYASINGHE, S.M., CRANE, J., REY, J.P., DIXON, M.J. and TRAINOR, P.A. (2006). Tcof1/Treacle is required for neural crest cell formation and proliferation deficiencies that cause craniofacial abnormalities. Proc. Natl. Acad. Sci. USA 103: 13403-13408.

DONAHUE, L.R., CHANG, B., MOHAN, S., MIYAKOSHI, N., WERGEDAL, J.E., BAYLINK, D.J., HAWES, N.L., ROSEN, C.J., WARD-BAILEY, P., ZHENG, Q.Y. et al. (2003). A missense mutation in the mouse Col2a1 gene causes spondyloepiphyseal dysplasia congenita, hearing loss and retinoschisis. J. Bone Miner. Res. 18: 1612-1621.

DONAUDY, F., FERRARA, A., ESPOSITO, L., HERTZANO, R., BEN-DAVID, O., BELL, R.E., MELCHIONDA, S., ZELANTE, L., AVRAHAM, K.B. and GASPARINI, P. (2003). Multiple mutations of MYO1A, a cochlear-expressed gene, in sensorineural hearing loss. Am. J. Hum. Genet. 72: 1571-1577.

DONAUDY, F., SNOECKX, R., PFISTER, M., ZENNER, H.P., BLIN, N., DISTAZIO, M., FERRARA, A., LANZARA, C., FICARELLA, R., DECLAU, F. et al. (2004). Nonmuscle myosin heavy-chain gene MYH14 is expressed in cochlea and mutated in patients affected by autosomal dominant hearing impairment (DFNA4). Am. J. Hum. Genet. 74: 770-776.

DONG, S., LEUNG, K.K., PELLING, A.L., LEE, P.Y., TANG, A.S., HENG, H.H., TSUI, L.C., TEASE, C., FISHER, G., STEEL, K.P. et al. (2002). Circling, deafness and yellow coat displayed by yellow submarine (ysb) and light coat and circling (ICC) mice with mutations on chromosome 3. Genomics 79: 777-784.

EIBERGER, J., KIBSCHULL, M., STRENZKE, N., SCHOBER, A., BUSSOW, H., WESSIG, C., DJAHED, S., REUCHER, H., KOCH, D.A., LAUTERMANN, J. et al. (2006). Expression pattern and functional characterization of connexin29 in transgenic mice. Glia 53: 601-611.

ERKMAN, L., MCEVILLY, R.J., LUO, L., RYAN, A.K., HOOSHMAND, F., O'CONNELL, S.M., KEITHLEY, E.M., RAPAPORT, D.H., RYAN, A.F. and ROSENFELD, M.G. (1996). Role of transcription factors Brn-3.1 and Brn-3.2 in auditory and visual system development. Nature 381: 603-606.

EUDY, J.D., WESTON, M.D., YAO, S., HOOVER, D.M., REHM, H.L., MA-EDMONDS, M., YAN, D., AHMAD, I., CHENG, J.J., AYUSO, C. et al. (1998). Mutation of a gene encoding a protein with extracellular matrix motifs in Usher syndrome type Ila. Science 280: 1753-1757

EVERETT, L.A., BELYANTSEVA, I.A., NOBEN-TRAUTH, K., CANTOS, R., CHEN, A., THAKKAR, S.I., HOOGSTRATEN-MILLER, S.L., KACHAR, B., WU, D.K. and GREEN, E.D. (2001). Targeted disruption of mouse Pds provides insight about the inner-ear defects encountered in Pendred syndrome. Hum. Mol. Genet. 10: 153-161.

EVERETT, L.A., GLASER, B., BECK, J.C., IDOL, J.R., BUCHS, A., HEYMAN, M., ADAWI, F., HAZANI, E., NASSIR, E., BAXEVANIS, A.D. et al. (1997). Pendred syndrome is caused by mutations in a putative sulphate transporter gene (PDS). Nat. Genet. 17: 411-422.
EVERETT, L.A., MORSLI, H., WU, D.K. and GREEN, E.D. (1999). Expression pattern of the mouse ortholog of the Pendred's syndrome gene (Pds) suggests a key role for pendrin in the inner ear. Proc. Natl. Acad. Sci. USA96: 9727-9732.

FANTES, J., RAGGE, N.K., LYNCH, S.A., MCGILL, N.I., COLLIN, J.R., HOWARDPEEBLES, P.N., HAYWARD, C., VIVIAN, A.J., WILLIAMSON, K., VAN HEYNINGEN, V. et al. (2003). Mutations in SOX2 cause anophthalmia. Nat. Genet. 33: 461-463.

FASSLER, R., SCHNEGELSBERG, P.N., DAUSMAN, J., SHINYA, T., MURAGAKI, Y., MCCARTHY, M.T., OLSEN, B.R. and JAENISCH, R. (1994). Mice lacking alpha 1 (IX) collagen develop noninflammatory degenerative joint disease. Proc. Natl. Acad. Sci. USA 91: 5070-5074.

FORGE, A., MARZIANO, N.K., CASALOTTI, S.O., BECKER, D.L. and JAGGER, D. (2003). The inner ear contains heteromeric channels composed of cx26 and cx30 and deafness-related mutations in cx26 have a dominant negative effect on cx30. Cell Commun. Adhes. 10: 341-346.

FOSTER, M.J., CALDWELL, A.P., STAHELI, J., SMITH, D.H., GARDNER, J.S. and SEEGMILLER, R.E. (1994). Pulmonary hypoplasia associated with reduced thoracic space in mice with disproportionate micromelia (DMM). Anat. Rec. 238: 454-462.

FRIEDMANN, I., FRASER, G.R. and FROGGATT, P. (1966). Pathology of the ear in the cardioauditory syndrome of Jervell and Lange-Nielsen (recessive deafness with electrocardiographic abnormalities). J. Laryngol. Otol. 80: 451-470

FRINGS, H., FRINGS, M. and KIVERT, A. (1951). Behavior patterns of the laboratory mouse under auditory stress. J. Mammal. 32: 60-76.

FROLENKOV, G.I. (2006). Regulation of electromotility in the cochlear outer hair cell. J. Physiol. 576: 43-48.

FROLENKOV, G.I., BELYANTSEVA, I.A., FRIEDMAN, T.B. and GRIFFITH, A.J. (2004). Genetic insights into the morphogenesis of inner ear hair cells. Nat. Rev. Genet. 5: 489-498.

GABRIEL, H.D., JUNG, D., BUTZLER, C., TEMME, A., TRAUB, O., WINTERHAGER, E. and WILLECKE, K. (1998). Transplacental uptake of glucose is decreased in embryonic lethal connexin26-deficient mice. J. Cel/ Biol. 140: 1453-1461.

GAGNON, L.H., LONGO-GUESS, C.M., BERRYMAN, M., SHIN, J.B., SAYLOR, K.W., YU, H., GILLESPIE, P.G. and JOHNSON, K.R. (2006). The chloride intracellular channel protein CLIC5 is expressed at high levels in hair cell stereocilia and is essential for normal inner ear function. J. Neurosci. 26: 1018810198.

GLASER, B. (2003). Pendred syndrome. Pediatr. Endocrinol. Rev. 1 Suppl 2: 199204; discussion 204.

GOODYEAR, R.J., MARCOTTI, W., KROS, C.J. and RICHARDSON, G.P. (2005) Development and properties of stereociliary link types in hair cells of the mouse cochlea. J. Comp. Neurol. 485: 75-85

GOODYEAR, R.J. and RICHARDSON, G.P. (2003). A novel antigen sensitive to calcium chelation that is associated with the tip links and kinocilial links of sensory hair bundles. J. Neurosci. 23: 4878-4887.

GRIFFITH, A.J., SPRUNGER, L.K., SIRKO-OSADSA, D.A., TILLER, G.E., MEISLER, M.H. and WARMAN, M.L. (1998). Marshall syndrome associated with a splicing defect at the COL11A1 locus. Am. J. Hum. Genet. 62: 816-823.

HAGSTROM, S.A., PAUER, G.J., REID, J., SIMPSON, E., CROWE, S., MAUMENEE, I.H. and TRABOULSI, E.I. (2005). SOX2 mutation causes anophthalmia, hearing loss and brain anomalies. Am. J. Med. Genet. A. 138: 95-98.

HAMPTON, L.L., WRIGHT, C.G., ALAGRAMAM, K.N., BATTEY, J.F. and NOBENTRAUTH, K. (2003). A new spontaneous mutation in the mouse Ames waltzer gene, Pcdh15. Hear. Res. 180: 67-75.

HASKO, J.A. and RICHARDSON, G.P. (1988). The ultrastructural organization and properties of the mouse tectorial membrane matrix. Hear. Res. 35: 21-38.

HEMMERT, W., ZENNER, H.P. and GUMMER, A.W. (2000). Three-dimensional motion of the organ of Corti. Biophys. J. 78: 2285-2297.

HERTZANO, R. and AVRAHAM, K.B. (2005). Developmental genes associated with human hearing loss. In Development of the Inner Ear (ed. KELLEY, M. W.WU, D. K.POPPER, A. N. and FAY, R. R.). Springer, New York, pp.204-232.

HERTZANO, R., DROR, A.A., MONTCOUQUIOL, M., AHMED, Z.M., ELLSWORTH, B., CAMPER, S., FRIEDMAN, T.B., KELLEY, M.W. and AVRAHAM, K.B. (2007). Lhx3, a LIM domain transcription factor, is regulated by Pou4f3 in the auditory but not in the vestibular system. Eur. J. Neurosci. 25: 999-1005.

HERTZANO, R., MONTCOUQUIOL, M., RASHI-ELKELES, S., ELKON, R., YUCEL, 
R., FRANKEL, W.N., RECHAVI, G., MOROY, T., FRIEDMAN, T.B., KELLEY, M.W. et al. (2004). Transcription profiling of inner ears from Pou4f3(ddl/ddl) identifies Gfi1 as a target of the Pou4f3 deafness gene. Hum. Mol. Genet. 13: 2143-2153.

HOLME, R.H. and STEEL, K.P. (2002). Stereocilia defects in waltzer (Cdh23), shaker1 (Myo7a) and double waltzer/shaker1 mutant mice. Hear. Res. 169: 1323.

HOLME, R.H. and STEEL, K.P. (2004). Progressive hearing loss and increased susceptibility to noise-induced hearing loss in mice carrying a Cdh23 but not a Myo7a mutation. J. Assoc. Res. Otolaryngol. 5: 66-79.

HUDSON, B.G., TRYGGVASON, K., SUNDARAMOORTHY, M. and NEILSON, E.G. (2003). Alport's syndrome, Goodpasture's syndrome and type IV collagen. N. Engl. J. Med. 348: 2543-2556.

HUGHES, D.C., LEGAN, P.K., STEEL, K.P. and RICHARDSON, G.P. (1998). Mapping of the alpha-tectorin gene (TECTA) to mouse chromosome 9 and human chromosome 11: a candidate for human autosomal dominant nonsyndromic deafness. Genomics 48: 46-51.

HULANDER, M., KIERNAN, A.E., BLOMQVIST, S.R., CARLSSON, P., SAMUELSSON, E.J., JOHANSSON, B.R., STEEL, K.P. and ENERBACK, S. (2003). Lack of pendrin expression leads to deafness and expansion of the endolymphatic compartment in inner ears of Foxi1 null mutant mice. Development 130: 2013-2025.

HYDE, M.L. (2005). Newborn hearing screening programs: overview. J. Otolaryngol. 34 Suppl 2: S70-78.

JABBA, S.V., OELKE, A., SINGH, R., MAGANTI, R.J., FLEMING, S., WALL, S.M., EVERETT, L.A., GREEN, E.D. and WANGEMANN, P. (2006). Macrophage invasion contributes to degeneration of stria vascularis in Pendred syndrome mouse model. BMC Med. 4: 37.

JACKSON LABORATORY (2007). Hereditary hearing impairment in mice: http:// www.jax.org/hmr/master_table.html

JIN, H., MAY, M., TRANEBJAERG, L., KENDALL, E., FONTAN, G., JACKSON, J., SUBRAMONY, S.H., ARENA, F., LUBS, H., SMITH, S. et al. (1996). A novel Xlinked gene, DDP, shows mutations in families with deafness (DFN-1), dystonia, mental deficiency and blindness. Nat. Genet. 14: 177-180

JOENSUU, T., HAMALAINEN, R., YUAN, B., JOHNSON, C., TEGELBERG, S., GASPARINI, P., ZELANTE, L., PIRVOLA, U., PAKARINEN, L., LEHESJOKI, A.E. et al. (2001). Mutations in a novel gene with transmembrane domains underlie Usher syndrome type 3. Am. J. Hum. Genet. 69: 673-684.

JOHNSON, K.R., ZHENG, Q.Y. and NOBEN-TRAUTH, K. (2006). Strain background effects and genetic modifiers of hearing in mice. Brain Res. 1091: 79-88.

JOHNSON, K.R., ZHENG, Q.Y., WESTON, M.D., PTACEK, L.J. and NOBENTRAUTH, K. (2005). The Mass 1 frings mutation underlies early onset hearing impairment in BUB/BnJ mice, a model for the auditory pathology of Usher syndrome IIC. Genomics 85: 582-590.

KAPPLER, J.A., STARR, C.J., CHAN, D.K., KOLLMAR, R. and HUDSPETH, A.J. (2004). A nonsense mutation in the gene encoding a zebrafish myosin $\mathrm{VI}$ isoform causes defects in hair-cell mechanotransduction. Proc. Natt. Acad. Sci. USA 101: 13056-13061.

KAROLYI, I.J., PROBST, F.J., BEYER, L., ODEH, H., DOOTZ, G., CHA, K.B., MARTIN, D.M., AVRAHAM, K.B., KOHRMAN, D., DOLAN, D.F. et al. (2003). Myo15 function is distinct from Myo6, Myo7a and pirouette genes in development of cochlear stereocilia. Hum. Mol. Genet. 12: 2797-2805.

KELBERMAN, D., RIZZOTI, K., AVILION, A., BITNER-GLINDZICZ, M., CIANFARANI, S., COLLINS, J., CHONG, W.K., KIRK, J.M., ACHERMANN, J.C., ROSS, R. et al. (2006). Mutations within Sox2/SOX2 are associated with abnormalities in the hypothalamo-pituitary-gonadal axis in mice and humans. $J$. Clin. Invest. 116: 2442-2455

KHARKOVETS, T., DEDEK, K., MAIER, H., SCHWEIZER, M., KHIMICH, D., NOUVIAN, R., VARDANYAN, V., LEUWER, R., MOSER, T. and JENTSCH, T.J. (2006). Mice with altered KCNQ4 K+ channels implicate sensory outer hair cells in human progressive deafness. Embo J25: 642-652.

KHARKOVETS, T., HARDELIN, J.P., SAFIEDDINE, S., SCHWEIZER, M., ELAMRAOUI, A., PETIT, C. and JENTSCH, T.J. (2000). KCNQ4, a K+ channel mutated in a form of dominant deafness, is expressed in the inner ear and the central auditory pathway. Proc. Natt. Acad. Sci. USA 97: 4333-4338.

KIERNAN, A.E., PELLING, A.L., LEUNG, K.K., TANG, A.S., BELL, D.M., TEASE, C., LOVELL-BADGE, R., STEEL, K.P. and CHEAH, K.S. (2005). Sox2 is required for sensory organ development in the mammalian inner ear. Nature 434: 1031-1035.

KIKUCHI, T., KIMURA, R.S., PAUL, D.L., TAKASAKA, T. and ADAMS, J.C. (2000). Gap junction systems in the mammalian cochlea. Brain Res. Brain Res. Rev. 32 163-166.

KNIPPER, M., CLAUSSEN, C., RUTTIGER, L., ZIMMERMANN, U., LULLMANNRAUCH, R., ESKELINEN, E.L., SCHRODER, J., SCHWAKE, M. and SAFTIG, P. (2006). Deafness in LIMP2-deficient mice due to early loss of the potassium channel KCNQ1/KCNE1 in marginal cells of the stria vascularis. J. Physiol. 576 : 73-86.

KONDOH, M., TAKAHASHI, A., FUJII, M., YAGI, K. and WATANABE, Y. (2006). A novel strategy for a drug delivery system using a claudin modulator. Biol. Pharm. Bull. 29: 1783-1789.

KREMER, H., VAN WIJK, E., MARKER, T., WOLFRUM, U. and ROEPMAN, R. (2006). Usher syndrome: molecular links of pathogenesis, proteins and pathways. Hum. Mol. Genet. 15 Spec No 2: R262-270.

KUBISCH, C., SCHROEDER, B.C., FRIEDRICH, T., LUTJOHANN, B., ELAMRAOUI, A., MARLIN, S., PETIT, C. and JENTSCH, T.J. (1999). KCNQ4, a novel potassium channel expressed in sensory outer hair cells, is mutated in dominant deafness. Cel/96: 437-446.

KUDO, T., KURE, S., IKEDA, K., XIA, A.P., KATORI, Y., SUZUKI, M., KOJIMA, K., ICHINOHE, A., SUZUKI, Y., AOKI, Y. et al. (2003). Transgenic expression of a dominant-negative connexin26 causes degeneration of the organ of Corti and non-syndromic deafness. Hum. Mol. Genet. 12: 995-1004.

LAGZIEL, A., AHMED, Z.M., SCHULTZ, J.M., MORELL, R.J., BELYANTSEVA, I.A and FRIEDMAN, T.B. (2005). Spatiotemporal pattern and isoforms of cadherin 23 in wild type and waltzer mice during inner ear hair cell development. Dev. Biol. 280: 295-306.

LALWANI, A.K., GOLDSTEIN, J.A., KELLEY, M.J., LUXFORD, W., CASTELEIN, C.M. and MHATRE, A.N. (2000). Human nonsyndromic hereditary deafness DFNA17 is due to a mutation in nonmuscle myosin MYH9. Am. J. Hum. Genet. 67: 1121-1128.

LEE, M.P., RAVENEL, J.D., HU, R.J., LUSTIG, L.R., TOMASELLI, G., BERGER R.D., BRANDENBURG, S.A., LITZI, T.J., BUNTON, T.E., LIMB, C. etal. (2000). Targeted disruption of the Kvlqt1 gene causes deafness and gastric hyperplasia in mice. J. Clin. Invest. 106: 1447-1455.

LEGAN, P.K., LUKASHKINA, V.A., GOODYEAR, R.J., KOSSI, M., RUSSELL, I.J. and RICHARDSON, G.P. (2000). A targeted deletion in alpha-tectorin reveals that the tectorial membrane is required for the gain and timing of cochlear feedback. Neuron 28: 273-285.

LEGAN, P.K., LUKASHKINA, V.A., GOODYEAR, R.J., LUKASHKIN, A.N., VERHOEVEN, K., VAN CAMP, G., RUSSELL, I.J. and RICHARDSON, G.P. (2005). A deafness mutation isolates a second role for the tectorial membrane in hearing. Nat. Neurosci. 8: 1035-1042.

LEGAN, P.K., RAU, A., KEEN, J.N. and RICHARDSON, G.P. (1997). The mouse tectorins. Modular matrix proteins of the inner ear homologous to components of the sperm-egg adhesion system. J. Biol. Chem. 272: 8791-8801.

LETTS, V.A., VALENZUELA, A., DUNBAR, C., ZHENG, Q.Y., JOHNSON, K.R. and FRANKEL, W.N. (2000). A new spontaneous mouse mutation in the Kcne1 gene. Mamm. Genome 11: 831-835.

LI, S.W., TAKANOSU, M., ARITA, M., BAO, Y., REN, Z.X., MAIER, A., PROCKOP, D.J. and MAYNE, R. (2001). Targeted disruption of Col11a2 produces a mild cartilage phenotype in transgenic mice: comparison with the human disorder otospondylomegaepiphyseal dysplasia (OSMED). Dev. Dyn. 222: 141-152.

LI, X.C., EVERETT, L.A., LALWANI, A.K., DESMUKH, D., FRIEDMAN, T.B., GREEN, E.D. and WILCOX, E.R. (1998). A mutation in PDS causes non syndromic recessive deafness. Nat. Genet. 18: 215-217.

LI, Y., LACERDA, D.A., WARMAN, M.L., BEIER, D.R., YOSHIOKA, H., NINOMIYA Y., OXFORD, J.T., MORRIS, N.P., ANDRIKOPOULOS, K., RAMIREZ, F. et al. (1995). A fibrillar collagen gene, Col11a1, is essential for skeletal morphogenesis. Cel/80: 423-430.

LIBERMAN, M.C., GAO, J., HE, D.Z., WU, X., JIA, S. and ZUO, J. (2002). Prestin is required for electromotility of the outer hair cell and for the cochlear amplifier. Nature 419: 300-304.

LIU, X., BULGAKOV, O.V., DARROW, K.N., PAWLYK, B., ADAMIAN, M. LIBERMAN, M.C. and LI, T. (2007). Usherin is required for maintenance of retinal photoreceptors and normal development of cochlear hair cells. Proc. 
Natl. Acad. Sci. USA 104: 4413-4418.

LIU, X.Z., OUYANG, X.M., XIA, X.J., ZHENG, J., PANDYA, A., LI, F., DU, L.L., WELCH, K.O., PETIT, C., SMITH, R.J. et al. (2003). Prestin, a cochlear motor protein, is defective in non-syndromic hearing loss. Hum. Mol. Genet. 12:11551162.

LUKASHKIN, A.N., LUKASHKINA, V.A., LEGAN, P.K., RICHARDSON, G.P. and RUSSELL, I.J. (2004). Role of the tectorial membrane revealed by otoacoustic emissions recorded from wild-type and transgenic Tecta(deltaENT/deltaENT) mice. J. Neurophysiol. 91: 163-171.

LYNCH, E.D., LEE, M.K., MORROW, J.E., WELCSH, P.L., LEON, P.E. and KING, M.C. (1997). Nonsyndromic deafness DFNA1 associated with mutation of a human homolog of the Drosophila gene diaphanous. Science 278: 1315-1318.

MADDOX, B.K., GAROFALO, S., HORTON, W.A., RICHARDSON, M.D. and TRUNE, D.R. (1998). Craniofacial and otic capsule abnormalities in a transgenic mouse strain with a Col2a1 mutation. J. Craniofac. Genet. Dev. Biol. 18 195-201.

MAKISHIMA, T., RODRIGUEZ, C.I., ROBERTSON, N.G., MORTON, C.C., STEWART, C.L. and GRIFFITH, A.J. (2005). Targeted disruption of mouse Coch provides functional evidence that DFNA9 hearing loss is not a $\mathrm{COCH}$ haploinsufficiency disorder. Hum. Genet. 118: 29-34.

MARCUS, D.C., SUNOSE, H., LIU, J., BENNETT, T., SHEN, Z., SCOFIELD, M.A. and RYAN, A.F. (1998). Protein kinase C mediates P2U purinergic receptor inhibition of $\mathrm{K}+$ channel in apical membrane of strial marginal cells. Hear. Res. 115: 82-92.

MARCUS, D.C., SUNOSE, H., LIU, J., SHEN, Z. and SCOFIELD, M.A. (1997). P2U purinergic receptor inhibits apical IsK/KvLQT1 channel via protein kinase $\mathrm{C}$ in vestibular dark cells. Am. J. Physiol. 273: C2022-2029.

MARCUS, D.C., WU, T., WANGEMANN, P. and KOFUJI, P. (2002). KCNJ10 (Kir4.1) potassium channel knockout abolishes endocochlear potential. Am. J. Physiol. Cell Physiol. 282: C403-407.

MCGEE, J., GOODYEAR, R.J., MCMILLAN, D.R., STAUFFER, E.A., HOLT, J.R., LOCKE, K.G., BIRCH, D.G., LEGAN, P.K., WHITE, P.C., WALSH, E.J. et al. (2006). The very large G-protein-coupled receptor VLGR1: a component of the ankle link complex required for the normal development of auditory hair bundles. J. Neurosci. 26: 6543-6553.

MCGUIRT, W.T., PRASAD, S.D., GRIFFITH, A.J., KUNST, H.P., GREEN, G.E., SHPARGEL, K.B., RUNGE, C., HUYBRECHTS, C., MUELLER, R.F., LYNCH, E. et al. (1999). Mutations in COL11A2 cause non-syndromic hearing loss (DFNA13). Nat. Genet. 23: 413-419.

MCMILLAN, D.R., KAYES-WANDOVER, K.M., RICHARDSON, J.A. and WHITE, P.C. (2002). Very large G protein-coupled receptor-1, the largest known cell surface protein, is highly expressed in the developing central nervous system. J. Biol. Chem. 277: 785-792.

MCMILLAN, D.R. and WHITE, P.C. (2004). Loss of the transmembrane and cytoplasmic domains of the very large G-protein-coupled receptor-1 (VLGR1 or Mass1) causes audiogenic seizures in mice. Mol. Cell. Neurosci. 26: 322-329.

MELCHIONDA, S., AHITUV, N., BISCEGLIA, L., SOBE, T., GLASER, F., RABIONET, R., ARBONES, M.L., NOTARANGELO, A., DI IORIO, E., CARELLA, M. et al. (2001). MYO6, the human homologue of the gene responsible for deafness in Snell's waltzer mice, is mutated in autosomal dominant nonsyndromic hearing loss. Am. J. Hum. Genet. 69: 635-640.

MICHEL, V., GOODYEAR, R.J., WEIL, D., MARCOTTI, W., PERFETTINI, I., WOLFRUM, U., KROS, C.J., RICHARDSON, G.P. and PETIT, C. (2005). Cadherin 23 is a component of the transient lateral links in the developing hair bundles of cochlear sensory cells. Dev. Biol. 280: 281-294.

MIZUTA, K., NOZAWA, O., MORITA, H. and HOSHINO, T. (1993). Scanning electron microscopy of age-related changes in the C57BL/6J mouse cochlea. Scanning Microsc. 7: 889-896.

MOCHIZUKI, T., LEMMINK, H.H., MARIYAMA, M., ANTIGNAC, C., GUBLER, M.C., PIRSON, Y., VERELLEN-DUMOULIN, C., CHAN, B., SCHRODER, C.H., SMEETS, H.J. et al. (1994). Identification of mutations in the alpha 3(IV) and alpha $4(\mathrm{IV})$ collagen genes in autosomal recessive Alport syndrome. Nat. Genet. 8: 77-81.

MOHIDDIN, S.A., AHMED, Z.M., GRIFFITH, A.J., TRIPODI, D., FRIEDMAN, T.B., FANANAPAZIR, L. and MORELL, R.J. (2004). Novel association of hypertrophic cardiomyopathy, sensorineural deafness and a mutation in unconventional myosin VI (MYO6). J. Med. Genet. 41: 309-314.
MURCIA, C.L. and WOYCHIK, R.P. (2001). Expression of Pcdh15 in the inner ear nervous system and various epithelia of the developing embryo. Mech. Dev. 105: 163-166.

MUSTAPHA, M., WEIL, D., CHARDENOUX, S., ELIAS, S., EL-ZIR, E., BECKMANN, J.S., LOISELET, J. and PETIT, C. (1999). An alpha-tectorin gene defect causes a newly identified autosomal recessive form of sensorineural pre-lingual nonsyndromic deafness, DFNB21. Hum. Mol. Genet. 8: 409-412.

NAKAYA, K., HARBIDGE, D.G., WANGEMANN, P., SCHULTZ, B.D., GREEN, E.D., WALL, S.M. and MARCUS, D.C. (2007). Lack of pendrin HCO3- transport elevates vestibular endolymphatic [Ca2+] by inhibition of acid-sensitive TRPV5 and TRPV6 channels. Am. J. Physiol. Renal Physiol. 292: F1314-1321.

NAKAYAMA, J., FU, Y.H., CLARK, A.M., NAKAHARA, S., HAMANO, K., IWASAKI, N., MATSUI, A., ARINAMI, T. and PTACEK, L.J. (2002). A nonsense mutation of the MASS1 gene in a family with febrile and afebrile seizures. Ann. Neurol. 52: 654-657

NEYROUD, N., TESSON, F., DENJOY, I., LEIBOVICI, M., DONGER, C., BARHANIN, J., FAURE, S., GARY, F., COUMEL, P., PETIT, C. etal. (1997). A novel mutation in the potassium channel gene KVLQT1 causes the Jervell and Lange-Nielsen cardioauditory syndrome. Nat. Genet. 15: 186-189.

NICOLAS, M., DEMEMES, D., MARTIN, A., KUPERSHMIDT, S. and BARHANIN, J. (2001). KCNQ1/KCNE1 potassium channels in mammalian vestibular dark cells. Hear. Res. 153: 132-145.

NIKKILA, H., MCMILLAN, D.R., NUNEZ, B.S., PASCOE, L., CURNOW, K.M. and WHITE, P.C. (2000). Sequence similarities between a novel putative G proteincoupled receptor and $\mathrm{Na}+/ \mathrm{Ca} 2+$ exchangers define a cation binding domain. Mol. Endocrinol. 14: 1351-1364

NIKOLOPOULOS, T.P., LIOUMI, D., STAMATAKI, S. and O'DONOGHUE, G.M. (2006). Evidence-based overview of ophthalmic disorders in deaf children: a literature update. Otol. Neurotol. 27: S1-24, discussion S20.

NIU, H., MAKMURA, L., SHEN, T., SHETH, S.S., BLAIR, K. and FRIEDMAN, R.A. (2006). Identification of two major loci that suppress hearing loss and cochlear dysmorphogenesis in Eya1bor/bor mice. Genomics 88: 302-308.

NOBEN-TRAUTH, K., ZHENG, Q.Y. and JOHNSON, K.R. (2003). Association of cadherin 23 with polygenic inheritance and genetic modification of sensorineural hearing loss. Nat. Genet. 35: 21-23.

NOWOTNY, M. and GUMMER, A.W. (2006). Nanomechanics of the subtectorial space caused by electromechanics of cochlear outer hair cells. Proc. Nat/. Acad. Sci. USA 103: 2120-2125.

PACE, J.M., LI, Y., SEEGMILLER, R.E., TEUSCHER, C., TAYLOR, B.A. and OLSEN, B.R. (1997). Disproportionate micromelia (Dmm) in mice caused by a mutation in the C-propeptide coding region of Col2a1. Dev. Dyn. 208: 25-33.

PARKER, L.L., GAO, J. and ZUO, J. (2006). Absence of hearing loss in a mouse model for DFNA17 and MYH9-related disease: the use of public gene-targeted ES cell resources. Brain Res. 1091: 235-242.

PAWLOWSKI, K.S., KIKKAWA, Y.S., WRIGHT, C.G. and ALAGRAMAM, K.N. (2006). Progression of inner ear pathology in Ames waltzer mice and the role of protocadherin 15 in hair cell development. J. Assoc. Res. Otolaryngol. 7: 83-94.

PENDRED, V. (1896). Deaf-mutism and goitre. Lancet II: 532.

PETERS, L.M., ANDERSON, D.W., GRIFFITH, A.J., GRUNDFAST, K.M., SAN AGUSTIN, T.B., MADEO, A.C., FRIEDMAN, T.B. and MORELL, R.J. (2002). Mutation of a transcription factor, TFCP2L3, causes progressive autosomal dominant hearing loss, DFNA28. Hum. Mol. Genet. 11: 2877-2885.

PETIT, C. (2006). From deafness genes to hearing mechanisms: harmony and counterpoint. Trends Mol. Med. 12: 57-64.

PROBST, F.J., FRIDELL, R.A., RAPHAEL, Y., SAUNDERS, T.L., WANG, A., LIANG, Y., MORELL, R.J., TOUCHMAN, J.W., LYONS, R.H., NOBEN-TRAUTH, K. et al. (1998). Correction of deafness in shaker-2 mice by an unconventional myosin in a BAC transgene. Science 280: 1444-1447.

RAPHAEL, Y. and ALTSCHULER, R.A. (2003). Structure and innervation of the cochlea. Brain. Res. Bull. 60: 397-422.

REINERS, J., NAGEL-WOLFRUM, K., JURGENS, K., MARKER, T. and WOLFRUM U. (2006). Molecular basis of human Usher syndrome: deciphering the meshes of the Usher protein network provides insights into the pathomechanisms of the Usher disease. Exp. Eye Res. 83: 97-119.

RHODES, C.R., HERTZANO, R., FUCHS, H., BELL, R.E., DE ANGELIS, M.H. STEEL, K.P. and AVRAHAM, K.B. (2004). A Myo7a mutation cosegregates with 
stereocilia defects and low-frequency hearing impairment. Mamm. Genome15: 686-697.

RIAZUDDIN, S., CASTELEIN, C.M., AHMED, Z.M., LALWANI, A.K., MASTROIANNI, M.A., NAZ, S., SMITH, T.N., LIBURD, N.A., FRIEDMAN, T.B., GRIFFITH, A.J. et al. (2000). Dominant modifier DFNM1 suppresses recessive deafness DFNB26. Nat. Genet. 26: 431-434.

RIAZUDDIN, S., KHAN, S.N., AHMED, Z.M., GHOSH, M., CAUTION, K., NAZLI, S., KABRA, M., ZAFAR, A.U., CHEN, K., NAZ, S. et al. (2006). Mutations in TRIOBP, which encodes a putative cytoskeletal-organizing protein, are associated with nonsyndromic recessive deafness. Am. J. Hum. Genet. 78: 137-143.

RICHARD, G., WHITE, T.W., SMITH, L.E., BAILEY, R.A., COMPTON, J.G., PAUL, D.L. and BALE, S.J. (1998). Functional defects of Cx26 resulting from a heterozygous missense mutation in a family with dominant deaf-mutism and palmoplantar keratoderma. Hum. Genet. 103: 393-399.

RICHARDS, A.J., YATES, J.R., WILLIAMS, R., PAYNE, S.J., POPE, F.M., SCOTT, J.D. and SNEAD, M.P. (1996). A family with Stickler syndrome type 2 has a mutation in the COL11A1 gene resulting in the substitution of glycine 97 by valine in alpha 1 (XI) collagen. Hum. Mol. Genet. 5: 1339-1343.

RICHARDSON, G.P., RUSSELL, I.J., DUANCE, V.C. and BAILEY, A.J. (1987). Polypeptide composition of the mammalian tectorial membrane. Hear. Res. 25: 45-60.

RIVAS, A. and FRANCIS, H.W. (2005). Inner ear abnormalities in a Kcnq1 (Kvlqt1) knockout mouse: a model of Jervell and Lange-Nielsen syndrome. Otol. Neurotol. 26: 415-424.

ROBERTSON, N.G., LU, L., HELLER, S., MERCHANT, S.N., EAVEY, R.D., MCKENNA, M., NADOL, J.B., JR., MIYAMOTO, R.T., LINTHICUM, F.H., JR., LUBIANCA NETO, J.F. et al. (1998). Mutations in a novel cochlear gene cause DFNA9, a human nonsyndromic deafness with vestibular dysfunction. Nat. Genet. 20: 299-303.

ROCHA-SANCHEZ, S.M., MORRIS, K.A., KACHAR, B., NICHOLS, D., FRITZSCH, B. and BEISEL, K.W. (2007). Developmental expression of Kcnq4 in vestibular neurons and neurosensory epithelia. Brain Res. 1139: 117-125.

ROYAUX, I.E., BELYANTSEVA, I.A., WU, T., KACHAR, B., EVERETT, L.A., MARCUS, D.C. and GREEN, E.D. (2003). Localization and functional studies of pendrin in the mouse inner ear provide insight about the etiology of deafness in pendred syndrome. J. Assoc. Res. Otolaryngol. 4: 394-404.

RUSSELL, I.J., LEGAN, P.K., LUKASHKINA, V.A., LUKASHKIN, A.N., GOODYEAR, R.J. and RICHARDSON, G.P. (2007). Sharpened cochlear tuning in a mouse with a genetically modified tectorial membrane. Nat. Neurosci. 10: 215-223.

RUSSELL, L.B. (1971). Definition of functional units in a small chromosomal segment of the mouse and its use in interpreting the nature of radiation-induced mutations. Mutat. Res. 11: 107-123.

RYAN, A.K. and ROSENFELD, M.G. (1997). POU domain family values: flexibility, partnerships and developmental codes. Genes Dev. 11: 1207-1225.

RZADZINSKA, A.K., DERR, A., KACHAR, B. and NOBEN-TRAUTH, K. (2005). Sustained cadherin 23 expression in young and adult cochlea of normal and hearing-impaired mice. Hear. Res. 208: 114-121.

SCHAIBLE, R.H. (1956). Ames waltzer. Mouse Newslett. 15: 29.

SCHNEIDER, M.E., DOSE, A.C., SALLES, F.T., CHANG, W., ERICKSON, F.L., BURNSIDE, B. and KACHAR, B. (2006). A new compartment at stereocilia tips defined by spatial and temporal patterns of myosin Illa expression. J. Neurosci. 26: 10243-10252.

SCHULZE-BAHR, E., WANG, Q., WEDEKIND, H., HAVERKAMP, W., CHEN, Q., SUN, Y., RUBIE, C., HORDT, M., TOWBIN, J.A., BORGGREFE, M. et al. (1997). KCNE1 mutations cause jervell and Lange-Nielsen syndrome. Nat. Genet. 17: 267-268.

SCOTT, D.A. and KARNISKI, L.P. (2000). Human pendrin expressed in Xenopus laevis oocytes mediates chloride/formate exchange. Am. J. Physiol. Cell Physiol. 278: C207-211.

SCOTT, D.A., WANG, R., KREMAN, T.M., SHEFFIELD, V.C. and KARNISKI, L.P. (1999). The Pendred syndrome gene encodes a chloride-iodide transport protein. Nat. Genet. 21: 440-443.

SCOTT, H.S., KUDOH, J., WATTENHOFER, M., SHIBUYA, K., BERRY, A., CHRAST, R., GUIPPONI, M., WANG, J., KAWASAKI, K., ASAKAWA, S. et al. (2001). Insertion of beta-satellite repeats identifies a transmembrane protease causing both congenital and childhood onset autosomal recessive deafness.
Nat. Genet. 27: 59-63

SEEGMILLER, R., FRASER, F.C. and SHELDON, H. (1971). A new chondrodys trophic mutant in mice. Electron microscopy of normal and abnormal chondrogenesis. J. Cell Biol. 48: 580-593.

SEEGMILLER, R.E., BROWN, K. and CHANDRASEKHAR, S. (1988). Histochemical, immunofluorescence and ultrastructural differences in fetal cartilage among three genetically distinct chondrodystrophic mice. Teratology 38: 579-592.

SEILER, C., BEN-DAVID, O., SIDI, S., HENDRICH, O., RUSCH, A., BURNSIDE, B., AVRAHAM, K.B. and NICOLSON, T. (2004). Myosin VI is required for structural integrity of the apical surface of sensory hair cells in zebrafish. Dev. Biol. 272: 328-338.

SELF, T., MAHONY, M., FLEMING, J., WALSH, J., BROWN, S.D. and STEEL, K.P (1998). Shaker-1 mutations reveal roles for myosin VIIA in both development and function of cochlear hair cells. Development 125: 557-566.

SELF, T., SOBE, T., COPELAND, N.G., JENKINS, N.A., AVRAHAM, K.B. and STEEL, K.P. (1999). Role of myosin VI in the differentiation of cochlear hair cells. Dev. Biol. 214: 331-341.

SENFTEN, M., SCHWANDER, M., KAZMIERCZAK, P., LILLO, C., SHIN, J.B., HASSON, T., GELEOC, G.S., GILLESPIE, P.G., WILLIAMS, D., HOLT, J.R. et al. (2006). Physical and functional interaction between protocadherin 15 and myosin VIla in mechanosensory hair cells. J. Neurosci. 26: 2060-2071.

SHAHIN, H., WALSH, T., SOBE, T., ABU SA'ED, J., ABU RAYAN, A., LYNCH, E.D. LEE, M.K., AVRAHAM, K.B., KING, M.C. and KANAAN, M. (2006). Mutations in a novel isoform of TRIOBP that encodes a filamentous-actin binding protein are responsible for DFNB28 recessive nonsyndromic hearing loss. Am. J. Hum. Genet. 78: 144-152.

SHIN, J.B., STREIJGER, F., BEYNON, A., PETERS, T., GADZALA, L., MCMILLEN, D., BYSTROM, C., VAN DER ZEE, C.E., WALLIMANN, T. and GILLESPIE, P.G. (2007). Hair bundles are specialized for ATP delivery via creatine kinase. Neuron 53: 371-386.

SIEMENS, J., KAZMIERCZAK, P., REYNOLDS, A., STICKER, M., LITTLEWOODEVANS, A. and MULLER, U. (2002). The Usher syndrome proteins cadherin 23 and harmonin form a complex by means of PDZ-domain interactions. Proc. Nat/. Acad. Sci. USA 99: 14946-14951.

SIEMENS, J.L., C., DUMONT, R.A., REYNOLDS, A., WILLIAMS, D.S., GILLESPIE, P.G. and MULLER, U. (2004). Cadherin 23 is a component of the tip link in haircell stereocilia. Nature 428: 950-955.

SKRADSKI, S.L., CLARK, A.M., JIANG, H., WHITE, H.S., FU, Y.H. and PTACEK, L.J. (2001). A novel gene causing a mendelian audiogenic mouse epilepsy. Neuron 31: 537-544.

SLEPECKY, N.B., CEFARATTI, L.K. and YOO, T.J. (1992). Type II and type IX collagen form heterotypic fibers in the tectorial membrane of the inner ear. Matrix 12: 80-86.

SNEAD, M.P. and YATES, J.R. (1999). Clinical and Molecular genetics of Stickler syndrome. J. Med. Genet. 36: 353-359.

SOLLNER, C., RAUCH, G.J., SIEMENS, J., GEISLER, R., SCHUSTER, S.C., MULLER, U. and NICOLSON, T. (2004). Mutations in cadherin 23 affect tip links in zebrafish sensory hair cells. Nature 428: 955-959.

STEYGER, P.S., FURNESS, D.N., HACKNEY, C.M. and RICHARDSON, G.P (1989). Tubulin and microtubules in cochlear hair cells: comparative immunocytochemistry and ultrastructure. Hear. Res. 42: 1-16.

STICKLER, G.B., BELAU, P.G., FARRELL, F.J., JONES, J.D., PUGH, D.G., STEINBERG, A.G. and WARD, L.E. (1965). Hereditary Progressive ArthroOphthalmopathy. Mayo Clin. Proc. 40: 433-455.

SUZUKI, N., ASAMURA, K., KIKUCHI, Y., TAKUMI, Y., ABE, S., IMAMURA, Y., HAYASHI, T., ASZODI, A., FASSLER, R. and USAMI, S. (2005). Type IX collagen knock out mouse shows progressive hearing loss. Neurosci. Res. 51: 293-298.

SZYMKO-BENNETT, Y.M., KURIMA, K., OLSEN, B., SEEGMILLER, R. and GRIFFITH, A.J. (2003). Auditory function associated with Col11a1 haploinsufficiency in chondrodysplasia (cho) mice. Hear. Res. 175: 178-182.

TANG, L.S., MONTEMAYOR, C. and PEREIRA, F.A. (2006a). Sensorineural hearing loss: potential therapies and gene targets for drug development. IUBMB Life 58: 525-530.

TANG, W., ZHANG, Y., CHANG, Q., AHMAD, S., DAHLKE, I., YI, H., CHEN, P., PAUL, D.L. and LIN, X. (2006b). Connexin29 is highly expressed in cochlear 
Schwann cells and it is required for the normal development and function of the auditory nerve of mice. J. Neurosci. 26: 1991-1999.

TEKIN, M., HISMI, B.O., FITOZ, S., OZDAG, H., CENGIZ, F.B., SIRMACI, A., ASLAN, I., INCEOGLU, B., YUKSEL-KONUK, E.B., YILMAZ, S.T. et al. (2007). Homozygous mutations in fibroblast growth factor 3 are associated with a new form of syndromic deafness characterized by inner ear agenesis, microtia and microdontia. Am. J. Hum. Genet. 80: 338-344.

TEUBNER, B., MICHEL, V., PESCH, J., LAUTERMANN, J., COHEN-SALMON, M., SOHL, G., JAHNKE, K., WINTERHAGER, E., HERBERHOLD, C., HARDELIN, J.P. et al. (2003). Connexin30 (Gjb6)-deficiency causes severe hearing impairment and lack of endocochlear potential. Hum. Mol. Genet. 12: 13-21.

THALMANN, I. (1993). Collagen of accessory structures of organ of Corti. Connect. Tissue Res. 29: 191-201.

TYSON, J., TRANEBJAERG, L., BELLMAN, S., WREN, C., TAYLOR, J.F., BATHEN, J., ASLAKSEN, B., SORLAND, S.J., LUND, O., MALCOLM, S. et al. (1997). IsK and KVLQT1: mutation in either of the two subunits of the slow component of the delayed rectifier potassium channel can cause Jervell and Lange-Nielsen syndrome. Hum. Mol. Genet. 6: 2179-2185.

USAMI, S., ABE, S., WESTON, M.D., SHINKAWA, H., VAN CAMP, G. and KIMBERLING, W.J. (1999). Non-syndromic hearing loss associated with enlarged vestibular aqueduct is caused by PDS mutations. Hum. Genet. 104: 188192.

VAHAVA, O., MORELL, R., LYNCH, E.D., WEISS, S., KAGAN, M.E., AHITUV, N., MORROW, J.E., LEE, M.K., SKVORAK, A.B., MORTON, C.C. et al. (1998). Mutation in transcription factor POU4F3 associated with inherited progressive hearing loss in humans. Science 279: 1950-1954.

VAN CAMP, G. and SMITH, R.J.H. (2006). Hereditary Hearing Loss Homepage: http://webhost.ua.ac.be/hhh/

VAN CAMP, G., SNOECKX, R.L., HILGERT, N., VAN DEN ENDE, J., FUKUOKA, H., WAGATSUMA, M., SUZUKI, H., SMETS, R.M., VANHOENACKER, F., DECLAU, F. etal. (2006). A new autosomal recessive form of Stickler syndrome is caused by a mutation in the COL9A1 gene. Am. J. Hum. Genet. 79: 449-457.

VAN DE WATER, T.R. and GALINOVIC-SCHWARTZ, V. (1987). Collagen type II in the otic extracellular matrix. Effect on inner ear development. Hear. Res. 30: 39-47.

VAN WIJK, E., KRIEGER, E., KEMPERMAN, M.H., DE LEENHEER, E.M., HUYGEN, P.L., CREMERS, C.W., CREMERS, F.P. and KREMER, H. (2003). A mutation in the gamma actin 1 (ACTG1) gene causes autosomal dominant hearing loss (DFNA20/26). J. Med. Genet. 40: 879-884.

VAN WIJK, E., VAN DER ZWAAG, B., PETERS, T., ZIMMERMANN, U., TE BRINKE, H., KERSTEN, F.F., MARKER, T., ALLER, E., HOEFSLOOT, L.H., CREMERS, C.W. et al. (2006). The DFNB31 gene product whirlin connects to the Usher protein network in the cochlea and retina by direct association with USH2A and VLGR1. Hum. Mol. Genet. 15: 751-765.

VERHOEVEN, K., VAN LAER, L., KIRSCHHOFER, K., LEGAN, P.K., HUGHES, D.C., SCHATTEMAN, I., VERSTREKEN, M., VAN HAUWE, P., COUCKE, P., CHEN, A. et al. (1998). Mutations in the human alpha-tectorin gene cause autosomal dominant non-syndromic hearing impairment. Nat. Genet. 19: 60-62.

VERPY, E., MASMOUDI, S., ZWAENEPOEL, I., LEIBOVICI, M., HUTCHIN, T.P., DEL CASTILLO, I., NOUAILLE, S., BLANCHARD, S., LAINE, S., POPOT, J.L. et al. (2001). Mutations in a new gene encoding a protein of the hair bundle cause non-syndromic deafness at the DFNB16 locus. Nat. Genet. 29: 345-349.

VETTER, D.E., MANN, J.R., WANGEMANN, P., LIU, J., MCLAUGHLIN, K.J., LESAGE, F., MARCUS, D.C., LAZDUNSKI, M., HEINEMANN, S.F. and BARHANIN, J. (1996). Inner ear defects induced by null mutation of the isk gene. Neuron 17: 1251-1264.

VIKKULA, M., MARIMAN, E.C., LUI, V.C., ZHIDKOVA, N.I., TILLER, G.E., GOLDRING, M.B., VAN BEERSUM, S.E., DE WAAL MALEFIJT, M.C., VAN DEN HOOGEN, F.H., ROPERS, H.H. et al. (1995). Autosomal dominant and recessive osteochondrodysplasias associated with the COL11A2 locus. Cel/ 80: 431-437.

WADA, T., WAKABAYASHI, Y., TAKAHASHI, S., USHIKI, T., KIKKAWA, Y., YONEKAWA, $\mathrm{H}$. and KOMINAMI, R. (2001). A point mutation in a cadherin gene, Cdh23, causes deafness in a novel mutant, Waltzer mouse niigata. Biochem. Biophys. Res. Commun. 283: 113-117.

WALSH, T., WALSH, V., VREUGDE, S., HERTZANO, R., SHAHIN, H., HAIKA, S. LEE, M.K., KANAAN, M., KING, M.C. and AVRAHAM, K.B. (2002). From flies' eyes to our ears: mutations in a human class III myosin cause progressive nonsyndromic hearing loss DFNB30. Proc. Natl. Acad. Sci. USA99: 7518-7523.

WANGEMANN, P. (2002). K+ cycling and the endocochlear potential. Hear. Res. 165: 1-9.

WANGEMANN, P., ITZA, E.M., ALBRECHT, B., WU, T., JABBA, S.V., MAGANTI, R.J., LEE, J.H., EVERETT, L.A., WALL, S.M., ROYAUX, I.E. et al. (2004). Loss of KCNJ10 protein expression abolishes endocochlear potential and causes deafness in Pendred syndrome mouse model. BMC Med. 2: 30.

WANGEMANN, P., NAKAYA, K., WU, T., MAGANTI, R.J., ITZA, E.M., SANNEMAN, J.D., HARBIDGE, D.G., BILLINGS, S. and MARCUS, D.C. (2007). Loss of cochlear $\mathrm{HCO}$ - secretion causes deafness via endolymphatic acidification and inhibition of $\mathrm{Ca} 2+$ reabsorption in a Pendred syndrome mouse model. $\mathrm{Am}$. J. Physiol. Renal Physiol. 292: F1345-1353.

WASHINGTON, J.L., 3RD, PITTS, D., WRIGHT, C.G., ERWAY, L.C., DAVIS, R.R. and ALAGRAMAM, K. (2005). Characterization of a new allele of Ames waltzer generated by ENU mutagenesis. Hear. Res. 202: 161-169.

WAYNE, S., ROBERTSON, N.G., DECLAU, F., CHEN, N., VERHOEVEN, K. PRASAD, S., TRANEBJARG, L., MORTON, C.C., RYAN, A.F., VAN CAMP, G. et al. (2001). Mutations in the transcriptional activator EYA4 cause late-onset deafness at the DFNA10 locus. Hum. Mol. Genet. 10: 195-200.

WESTON, M.D., LUIJENDIJK, M.W., HUMPHREY, K.D., MOLLER, C. and KIMBERLING, W.J. (2004). Mutations in the VLGR1 gene implicate G-protein signaling in the pathogenesis of Usher syndrome type II. Am. J. Hum. Genet.74: 357-366.

WHITE, K.R. (2004). Early hearing detection and intervention programs: opportunities for genetic services. Am. J. Med. Genet. A. 130: 29-36.

WILCOX, E.R., BURTON, Q.L., NAZ, S., RIAZUDDIN, S., SMITH, T.N., PLOPLIS, B., BELYANTSEVA, I., BEN-YOSEF, T., LIBURD, N.A., MORELL, R.J. et al. (2001). Mutations in the gene encoding tight junction claudin-14 cause autosomal recessive deafness DFNB29. Cel/104: 165-172.

WILSON, S.M., HOUSEHOLDER, D.B., COPPOLA, V., TESSAROLLO, L., FRITZSCH, B., LEE, E.C., GOSS, D., CARLSON, G.A., COPELAND, N.G. and JENKINS, N.A. (2001). Mutations in Cdh23 cause nonsyndromic hearing loss in waltzer mice. Genomics 74: 228-233

WINTER, H., BRAIG, C., ZIMMERMANN, U., GEISLER, H.S., FRANZER, J.T., WEBER, T., LEY, M., ENGEL, J., KNIRSCH, M., BAUER, K. et al. (2006) Thyroid hormone receptors TRalpha1 and TRbeta differentially regulate gene expression of Kcnq4 and prestin during final differentiation of outer hair cells. J. Cell Sci. 119: 2975-2984.

WOOD, H.B. and EPISKOPOU, V. (1999). Comparative expression of the mouse Sox 1 , Sox 2 and Sox3 genes from pre-gastrulation to early somite stages. Mech. Dev. 86: 197-201.

WU, X., GAO, J., GUO, Y. and ZUO, J. (2004). Hearing threshold elevation precedes hair-cell loss in prestin knockout mice. Brain Res. Mol. Brain Res. 126: 30-37.

XIANG, M., GAN, L., LI, D., CHEN, Z.Y., ZHOU, L., O'MALLEY, B.W., JR., KLEIN, W. and NATHANS, J. (1997). Essential role of POU-domain factor Brn-3c in auditory and vestibular hair cell development. Proc. Natl. Acad. Sci. USA 94: 9445-9450.

XIANG, M., GAO, W.Q., HASSON, T. and SHIN, J.J. (1998). Requirement for Brn$3 \mathrm{c}$ in maturation and survival, but not in fate determination of inner ear hair cells. Development 125: 3935-3946.

XIAO, S., YU, C., CHOU, X., YUAN, W., WANG, Y., BU, L., FU, G., QIAN, M., YANG, J., SHI, Y. et al. (2001). Dentinogenesis imperfecta 1 with or without progressive hearing loss is associated with distinct mutations in DSPP. Nat. Genet. 27: 201204.

YAGI, H., TAKAMURA, Y., YONEDA, T., KONNO, D., AKAGI, Y., YOSHIDA, K. and SATO, M. (2005). Vlgr1 knockout mice show audiogenic seizure susceptibility. J. Neurochem. 92: 191-202.

YAGI, H., TOKANO, H., MAEDA, M., TAKABAYASHI, T., NAGANO, T., KIYAMA, H., FUJIEDA, S., KITAMURA, K. and SATO, M. (2007). VIgr1 is required for proper stereocilia maturation of cochlear hair cells. Genes Cells 12: 235-250.

YAMAMOTO, N., TANIGAKI, K., TSUJI, M., YABE, D., ITO, J. and HONJO, T. (2006). Inhibition of Notch/RBP-J signaling induces hair cell formation in neonate mouse cochleas. J. Mol. Med. 84: 37-45.

YAMASAKI, M., KOMUNE, S., SHIMOZONO, M., MATSUDA, K. and HARUTA, A. 
(2000). Development of monovalent ions in the endolymph in mouse cochlea. ORL J. Otorhinolaryngol. Relat. Spec. 62: 241-246.

YANG, J.J., HUANG, S.H., CHOU, K.H., LIAO, P.J., SU, C.C. and LI, S.Y. (2007). Identification of Mutations in Members of the Connexin Gene Family as a Cause of Nonsyndromic Deafness in Taiwan. Audiol. Neurootol. 12: 198-208.

YOSHINO, T., SATO, E., NAKASHIMA, T., NAGASHIMA, W., TERANISHI, M.A., NAKAYAMA, A., MORI, N., MURAKAMI, H., FUNAHASHI, H. and IMAI, T. (2004). The immunohistochemical analysis of pendrin in the mouse inner ear. Hear. Res. 195: 9-16.

YOSHINO, T., SATO, E., NAKASHIMA, T., TERANISHI, M., YAMAMOTO, H., OTAKE, H. and MIZUNO, T. (2006). Distribution of pendrin in the organ of Corti of mice observed by electron immunomicroscopy. Eur. Arch. Otorhinolaryngol. 263: 699-704.

YOUNG, T.L., IVES, E., LYNCH, E., PERSON, R., SNOOK, S., MACLAREN, L., CATER, T., GRIFFIN, A., FERNANDEZ, B., LEE, M.K. et al. (2001). Nonsyndromic progressive hearing loss DFNA38 is caused by heterozygous missense mutation in the Wolfram syndrome gene WFS1. Hum. Mol. Genet. 10: 2509-2514.

YU, N., ZHU, M.L. and ZHAO, H.B. (2006). Prestin is expressed on the whole outer hair cell basolateral surface. Brain Res. 1095: 51-58.

ZELANTE, L., GASPARINI, P., ESTIVILL, X., MELCHIONDA, S., D'AGRUMA, L., GOVEA, N., MILA, M., MONICA, M.D., LUTFI, J., SHOHAT, M. et al. (1997). Connexin26 mutations associated with the most common form of non-syndromic neurosensory autosomal recessive deafness (DFNB1) in Mediterraneans. Hum. Mol. Genet. 6: 1605-1609.

ZHAO, H.B., KIKUCHI, T., NGEZAHAYO, A. and WHITE, T.W. (2006). Gap junctions and cochlear homeostasis. J. Membr. Biol. 209: 177-186.

ZHENG, J., SHEN, W., HE, D.Z., LONG, K.B., MADISON, L.D. and DALLOS, P. (2000). Prestin is the motor protein of cochlear outer hair cells. Nature 405: 149155.

ZHENG, Q.Y. and JOHNSON, K.R. (2001). Hearing loss associated with the modifier of deaf waddler (mdfw) locus corresponds with age-related hearing loss in 12 inbred strains of mice. Hear. Res. 154: 45-53.

ZHENG, Q.Y., JOHNSON, K.R. and ERWAY, L.C. (1999). Assessment of hearing in 80 inbred strains of mice by ABR threshold analyses. Hear. Res. 130: 94-107.

ZHENG, Q.Y., YAN, D., OUYANG, X.M., DU, L.L., YU, H., CHANG, B., JOHNSON, K.R. and LIU, X.Z. (2005). Digenic inheritance of deafness caused by mutations in genes encoding cadherin 23 and protocadherin 15 in mice and humans. Hum. Mol. Genet. 14: 103-111.

ZHU, M., YANG, T., WEI, S., DEWAN, A.T., MORELL, R.J., ELFENBEIN, J.L., FISHER, R.A., LEAL, S.M., SMITH, R.J. and FRIDERICI, K.H. (2003). Mutations in the gamma-actin gene (ACTG1) are associated with dominant progressive deafness (DFNA20/26). Am. J. Hum. Genet. 73: 1082-1091.

ZWAENEPOEL, I., MUSTAPHA, M., LEIBOVICI, M., VERPY, E., GOODYEAR, R., LIU, X.Z., NOUAILLE, S., NANCE, W.E., KANAAN, M., AVRAHAM, K.B. et al. (2002). Otoancorin, an inner ear protein restricted to the interface between the apical surface of sensory epithelia and their overlying acellular gels, is defective in autosomal recessive deafness DFNB22. Proc. Natl. Acad. Sci. USA99:62406245.

\author{
Related, previously published Int. J. Dev. Biol. articles \\ See our Special Issue Ear Development edited by Fernando Giraldez and Bernd Fritzsch at: \\ http://www.ijdb.ehu.es/web/contents.php?vol=51\&issue=6-7
}

Analysis of Netrin 1 receptors during inner ear development

Tanja Matilainen, Maarja Haugas, Jordan A. Kreidberg and Marjo Salminen

Int. J. Dev. Biol. (2007) 51: 409-414

Cell proliferation during the early compartmentalization of the Xenopus laevis inner ear Quincy A. Quick and Elba E. Serrano

Int. J. Dev. Biol. (2007) 51: 201-210

Functional analysis of FGF3 during zebrafish inner ear development $\checkmark$ Vendrell, D Gimnopoulos, T Becker, T Schimmang

Int. J. Dev. Biol. (2001) 45: S105-S106

Role of Raf kinases during inner ear development.

C Sanz, Y Leon, M Garcia-Gil and I Varela-Nieto

Int. J. Dev. Biol. (1996) 40: S83-S84

p75 and Trk oncoproteins expression is developmentally regulated in the inner ear of human embryos.

E Vazquez, I San José, J Naves, J A Vega and J Represa

Int. J. Dev. Biol. (1996) 40: S77-S78 